\title{
16. SEISMIC-REFLECTION STRUCTURE OF THE UPPER OCEANIC CRUST: IMPLICATIONS FROM DSDP/ODP HOLE 504B, PANAMA BASIN 1
}

\author{
John A. Collins, ${ }^{2}$ Thomas M. Brocher, ${ }^{3}$ and G. Michael Purdy ${ }^{2}$
}

\begin{abstract}
We investigate the seismic reflectivity structure of the upper oceanic crust by comparing multichannel seismic (MCS) reflection data collected at DSDP/ODP Hole 504B to the results of downhole logging. At this site drilling shows a welldefined change in physical properties at depths within the basement of about $0.5-0.6 \mathrm{~km}$, corresponding to the downward transition from volcanic rocks to dikes. Extensive processing of the MCS data, required to remove high-amplitude side-scattered arrivals, revealed no conclusive evidence for laterally coherent reflection events generated within the upper $1-2 \mathrm{~km}$ of the crust. The crustal traveltime to the volcanic/dike boundary (about $0.25 \mathrm{~s}$ ) is similar to the traveltimes of shallow reflection events observed in other areas. In an attempt to understand the lack of reflectivity from the volcanic/ dike boundary at Hole 504B, we calculated synthetic reflection seismograms for a series of velocity-depth profiles constructed from the logged downhole variations in physical properties. These seismograms were calculated with the source signature of the 1785 -in. ${ }^{3}$ (29.3-L) air gun array used to acquire the MCS data. The synthetic seismograms demonstrate that the reflections from the shallow crust are low in amplitude and may be obscured by source reverberation and by sediment-column multiples. Nonetheless, the limited available data also suggest that the upper crustal structure at Hole 504B may in fact differ from that at other crustal sites where high-amplitude reflections from within the shallow crust have been observed.
\end{abstract}

\section{INTRODUCTION}

The application of near-normal-incidence, multichannel seismic (MCS) reflection profiling techniques to the study of oceanic crustal structure has resulted in the detection and mapping of reflecting horizons both within the crust and at the crust/ mantle boundary. Shallow and deep intracrustal events (e.g., Musgrove and Austin, 1983; Mutter and NAT Study Group, 1985; McCarthy et al., 1988; Rohr et al., 1988), proposed magma chamber reflection events (Herron et al., 1978; Hale et al., 1982; Morton and Sleep, 1985; Detrick et al., 1987; Rohr et al., 1988), and Moho reflections (e.g., Stoffa et al., 1980; Grow and Markl, 1977; Mutter and NAT Study Group, 1985) have been identified. The high spatial resolution and profiling rates attainable with the MCS technique, together with the interpretable seismic images that comprise the processed data, result in this technique being a powerful tool for mapping variations in seismic structure over a wide range of length scales. One of the first studies of oceanic crustal structure using MCS techniques consisted of the 1974 acquisition of a $3400-\mathrm{km}$-long profile extending from the United States continental margin to the MidAtlantic Ridge (Grow and Markl, 1977). Since then, thousands to tens of thousands of kilometers of MCS data have been acquired on oceanic crust. In contrast to commonly observed reflections from the crust/mantle boundary, upper- and midcrustal reflection events (Table 1) have been reported less frequently.

A limitation of the MCS technique is the difficulty in obtaining accurate interval velocities within the oceanic crust. Reflection amplitudes are a function of seismic impedance, but it is difficult to determine the impedance structure of oceanic crust

\footnotetext{
${ }^{1}$ Becker, K., Sakai, H., et al., 1989. Proc. ODP, Sci. Results, 111: College Station, TX (Ocean Drilling Program).

2 Woods Hole Oceanographic Institution, Woods Hole, MA 02543 (Collins, present address: Research School of Earth Sciences, The Australian National University, GPO Box 4, Canberra, 2601 A.C.T., Australia).

3 U.S. Geological Survey, 345 Middlefield Road, M/S 977, Menlo Park, CA 94025 .
}

Table 1. Characteristics of upper and middle crust reflections.

\begin{tabular}{|c|c|c|c|c|c|}
\hline Location & $\begin{array}{l}\text { Traveltime } \\
\text { within } \\
\text { basement } \\
\text { (s) }\end{array}$ & $\begin{array}{l}\text { Crustal } \\
\text { thickness } \\
\text { (s) }\end{array}$ & $\begin{array}{c}\text { CMP } \\
\text { fold/ } \\
\text { aperture } \\
(\mathrm{km})\end{array}$ & $\begin{array}{r}\text { So } \\
\left(\text { in. }{ }^{3}\right)\end{array}$ & (L) \\
\hline${ }^{a}$ Angola Basin & $0.25-0.4$ & $1.6-1.9$ & $12 / 2.7$ & 4500 & 73.7 \\
\hline${ }^{\mathrm{b}}$ Western Atlantic & $0.6-1.0$ & $2.5-3.0$ & $60 / 6$ & $\begin{array}{l}3300 \\
2932\end{array}$ & $\begin{array}{l}54 \\
48\end{array}$ \\
\hline $\begin{array}{c}{ }^{c} \text { Juan de Fuca } \\
\text { Ridge }\end{array}$ & $0.3-0.55$ & 2.2 & $60 / 3$ & 6000 & 98 \\
\hline
\end{tabular}

a Musgrove and Austin (1983).

b Mutter and NAT Study Group (1985); McCarthy et al. (1988).

${ }^{\mathrm{c}}$ Rohr et al. (1988).

because of the typically low signal-to-noise ratios of near-normal-incidence intracrustal and Moho reflection events. Consequently, the primary information retrievable from MCS data is the traveltime to a given reflector. In contrast to MCS techniques, the wide-angle reflection/refraction method allows the determination of seismic velocities, quantitative numbers that are readily compared to the results of other experiments. Optimally, wide-angle reflection/refraction and near-normal-incidence MCS data are collected simultaneously. Such experiments allow the depth determination of a reflective horizon within the layered velocity structure characteristic of oceanic crust. Although the shallow reflection events summarized in Table 1 can be identified with confidence, the lack of co-incident wide-angle reflection/refraction data prevents correlating these reflections to the layered velocity structure characteristic of the oceanic crust.

While combined MCS and wide-angle reflection/refraction techniques provide a clear picture of oceanic seismic structure, the large number of parameters that control rock velocity (e. g., Purdy and Ewing, 1986) makes it difficult to correlate seismic and geological structure. Marine seismologists typically relate the layered velocity-depth structure that they derive from refraction experiments to geological structure in terms of the vertical distribution of lithologies that are found in ophiolite sequences. 
In this approach, seismic Layer 2 is correlated with volcanic and sheeted dike sequences, seismic Layer 3 is correlated with a gabbroic sequence, and mantle velocities of $8.0 \mathrm{~km} / \mathrm{s}$ or greater are associated with residual ultramafic rocks. Similarly, observed MCS reflection events are often associated with these geological boundaries. However, the validity of the ophiolite model of oceanic crustal stratigraphy is uncertain. An alternative viewpoint is that observed velocity layering and reflection events can be correlated with approximately constant maximum depths of chemical alteration and cracking in either a compositionally homogeneous or layered crust (e.g., Lewis, 1983).

It is tempting to relate the reflection events of Table 1 to one or more of the geological boundaries recognized in ophiolites, namely the volcanic/sheeted dike, greenschist facies/amphibolite facies, and sheeted dike/gabbro transitions. Ophiolite studies show that the depths, thicknesses, and geologic character of these geological boundaries vary by hundreds of meters over length scales of a few kilometers (Casey et al., 1981), in agreement with the variable traveltimes and discontinuous occurrence of these shallow reflection events. However, correlating these events to geological boundaries is ambiguous without direct sampling of the reflecting boundaries by crustal drilling.

In this paper, we investigate the seismic reflectivity structure of the upper 1-2 km of oceanic crust by comparing MCS reflection data collected at Deep Sea Drilling Project/Ocean Drilling Program (DSDP/ODP) Hole 504B to synthetic reflection seismograms computed for velocity-depth profiles constructed from downhole logging of physical properties. Hole 504B has been drilled to a total basement depth of $1.288 \mathrm{~km}$ and is the deepest drill hole into oceanic crust at the time of writing. Hole 504B is the only location where the volcanic/dike boundary, predicted by the ophiolite model to be a fundamental feature of oceanic crust, has been drilled. The downward change in rock type coincides with changes in a variety of logged physical properties. The normal-incidence traveltime to this boundary is similar to the traveltimes of shallow reflection events observed in other areas (e.g., Table 1). Accordingly, Hole 504B appears to be an ideal location to test the hypothesis that shallow reflection events (Table 1) correlate with the downward transition from volcanic rocks to dikes.

\section{STUDY AREA}

DSDP/ODP Hole 504B is located on the Nazca plate, about $225 \mathrm{~km}$ south of the Costa Rica Rift, the easternmost segment of the Cocos/Nazca plate boundary (Fig. 1). Water depth and sediment thickness at the drill site are $3460 \mathrm{~m}$ and $275 \mathrm{~m}$, respectively, and the crustal age is estimated to be 5.9 m.y. (Hobart et al., 1985). Within a radius of $50 \mathrm{~km}$ about the drill site, basement topography has amplitudes typically less than $100 \mathrm{~m}$ (Langseth et al., 1983); basement topographic highs strike eastwest, parallel to the Costa Rica Rift (Searle, 1983).

The sedimentary sequence at Hole 504B consists of three lithologic units (Fig. 2). Unit 1, extending from the seafloor to a depth of $145 \mathrm{~m}$ below seafloor (mbsf), consists of nannofossil oozes that are characterized by a mean compressional-wave velocity and density of about $1.51 \mathrm{~km} / \mathrm{s}$ and about $1.32 \mathrm{~g} / \mathrm{cm}^{3}$, respectively (Wilkens and Langseth, 1983). Unit 2, extending to a depth of 227 mbsf, consists of chalks that are characterized by a mean compressional-wave velocity and density of about 1.53 $\mathrm{km} / \mathrm{s}$ and $1.48 \mathrm{~g} / \mathrm{cm}^{3}$, respectively. Lying immediately above basement, Unit 3 consists of up to $30 \mathrm{~m}$ of interbedded limestones and cherts (CRRUST, 1982). A compressional-wave velocity of $4.25 \mathrm{~km} / \mathrm{s}$ was measured for a chert sample from Unit 3 (Wilkens and Langseth, 1983). All of these velocities for the sediments were measured at room pressure.

From the top of oceanic crust downward (Fig. 2), the drilled igneous sequence consists of $0.575 \mathrm{~km}$ of basaltic flows and pil- lows, $0.209 \mathrm{~km}$ of mixed extrusive/intrusive basaltic rocks, and finally $0.504 \mathrm{~km}$ of diabase dikes (Anderson et al., 1982; Shipboard Scientific Party, 1988). The latter are distinguished from extrusive rocks on the basis of texture and the absence of volcanic glass (Anderson et al., 1982). The vertical sequence of extrusives and dikes drilled at Hole 504B is consistent with the ophiolite model of oceanic crust (e.g., Coleman, 1977). Consequently, the dike succession at Hole 504B is interpreted as a sheeted dike sequence. Velocity-depth profiles determined from wide-angle reflection/refraction experiments (Little and Stephen, 1985; Collins, 1989) suggest that the current bottom of the drill hole is near the Layer 2/Layer 3 transition (Fig. 2B).

Hole 504B is unique in the great variety of geophysical experiments that have been carried out downhole. Multichannel compressional $(P-)$ and shear $(S-)$ wave sonic velocity logs, active-source neutron and gamma-ray logs, conventional and largeaperture (10-80-m) electrical resistivity logs, and borehole televiewer logs are discussed by Anderson et al. (1982, 1985a), Becker (1985), Newmark et al. (1985), and Moos et al. (1986). Variations in crustal permeability and in borehole heat flow are described by Anderson et al. (1985b) and Becker et al. (1985).

Inspection of the logged physical properties at Hole 504B demonstrates that electrical resistivity, as determined by the large-aperture array (Becker, 1985), shows the greatest variation as a function of depth. Resistivity values increase by about two orders of magnitude downhole, indicating a decrease in bulk porosity of about $10 \%-15 \%$ in the same direction (Becker, 1985). In contrast to conventionally acquired resistivity data, the large-aperture data are less affected by borehole drilling fluids and drilling-induced fracture porosity and are thought to be representative of the resistivity structure at distances of tens of meters-instead of centimeters-from the borehole. The largeaperture resistivity data also represent averages over length scales that are more appropriate for comparison to controlled-source seismic experiments. Salisbury et al. (1985) showed that bulk porosity, rather than rock type and composition, is the primary control on the $P$-wave velocity of the upper crust at Hole 504B. Estimates of fracture porosity at Hole 504B, derived by subtracting laboratory-measured porosities from the bulk porosity data, show that fracture porosity decreases to near zero toward the bottom of the drill hole (Salisbury et al., 1985). This decrease is at least partially explained by filling of porosity by alteration products.

The recognition of seismic Layers $2 \mathrm{~A}, 2 \mathrm{~B}$, and $2 \mathrm{C}$ in the upper 1-2 km of oceanic crust (e.g., Houtz and Ewing, 1976) has prompted a search for three zones of distinctive physical properties at Hole 504B. Such a subdivision is readily recognized in the estimates of bulk porosity derived from the large-aperture resistivity data (Fig. 2A). These data are characterized by two zones of rapidly decreasing porosity as a function of depth that are separated by a zone where the porosity is approximately constant. Correlating the location of the changes in porosity gradient with the Layers $2 \mathrm{~A} / 2 \mathrm{~B}$ and $2 \mathrm{~B} / 2 \mathrm{C}$ boundaries indicates that these layers are about 200,350 , and greater than $500 \mathrm{~m}$ thick, respectively. Porosity decreases by about $5 \%$ over a distance of about $50 \mathrm{~m}$ across the volcanic/sheeted dike transition (Layers 2B/2C boundary). Anderson et al. (1985a) described similar changes in gradient in other logged physical properties. Layers $2 \mathrm{~A}$ and $2 \mathrm{~B}$ are less readily distinguished in the sonic velocity data, and Layer 2A cannot be identified in borehole seismic data (Little and Stephen, 1985; Stephen, 1985), presumably because of its local occurrence and/or its limited thickness (Fig. 2).

\section{MCS DATA}

In May 1985, Robert D. Conrad was used to collect approximately $1700 \mathrm{~km}$ of MCS data in the vicinity of Hole 504B (Fig. 1). The primary objective of this experiment was to conduct a re- 

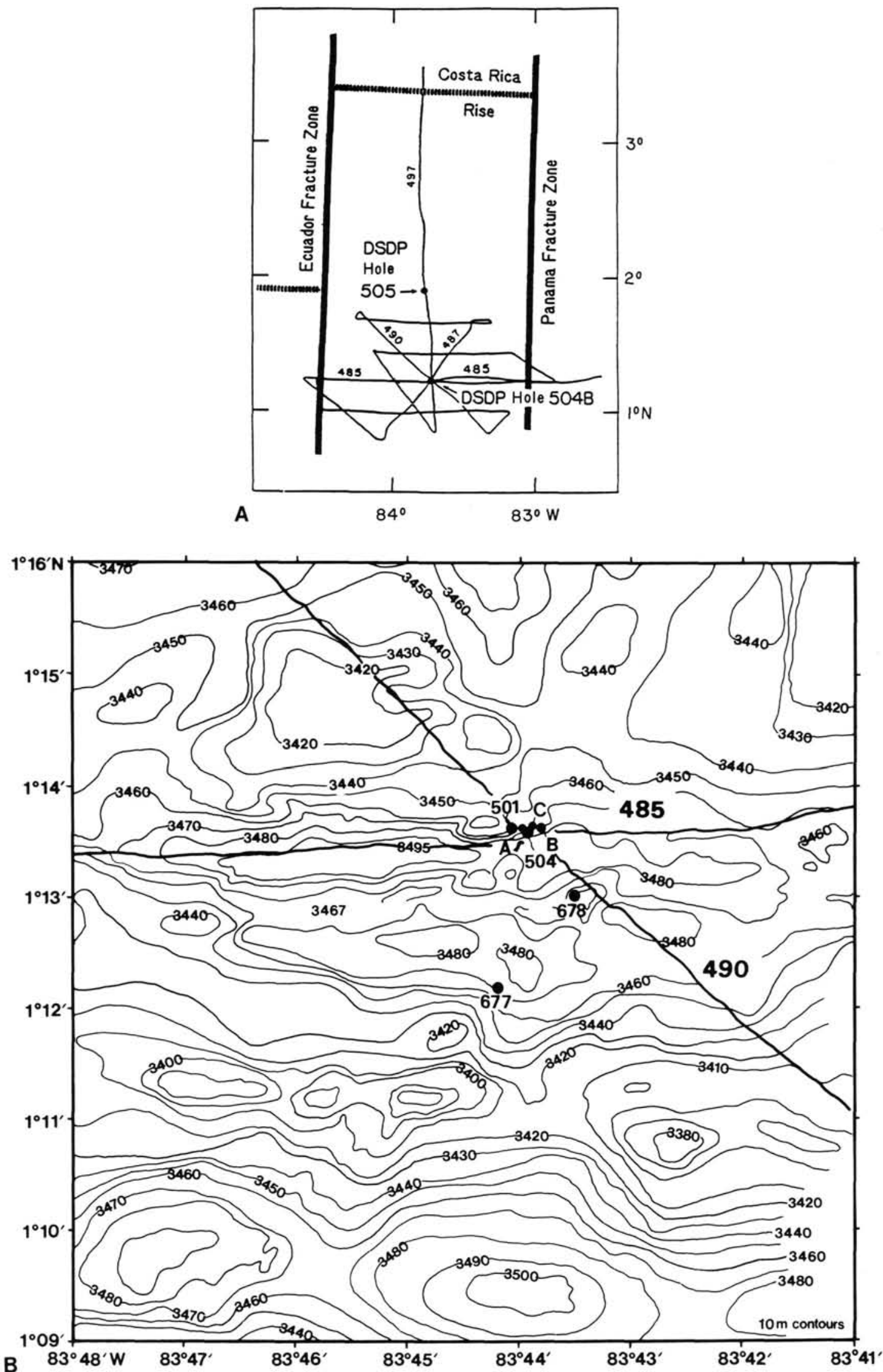

Figure 1. Location of Holes 501, 504B, 505, 677, and 678. A. MCS track lines for Robert D. Conrad Cruise 2606. B. Bathymetry in the immediate vicinity of the drill site (from Langseth et al., 1988). Locations of MCS lines 485 and 490 are shown relative to the locations of DSDP and ODP drill sites (dots). 

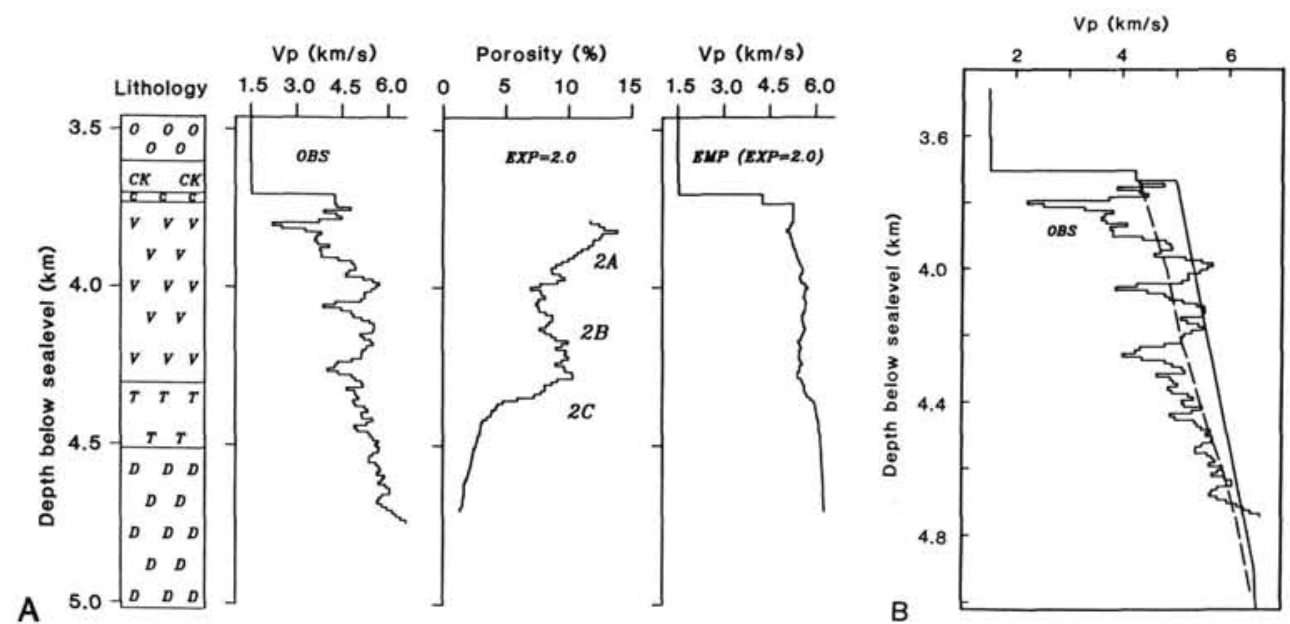

Figure 2. A. Schematic representation of the drilled sedimentary and igneous sequences at Hole 504B. Lithology: $\mathrm{O}=$ nannofossil ooze; $\mathrm{CK}=$ chalks; $\mathrm{C}=$ cherts; $\mathrm{V}=$ extrusive volcanics; $\mathrm{T}=$ volcanic/sheeted dike transition; $\mathrm{D}=$ sheeted dike sequence. The sonic velocity (model OBS) profile on the left was acquired on DSDP Leg 83 (Salisbury et al., 1985). Model OBS is the observed sonic velocity data averaged into 10$\mathrm{m}$-thick layers. The bulk porosity-depth model was calculated from a large-aperture resistivity log using an exponent of 2.0 for Archie's law (Becker, 1985). The velocity (EMP20) profile on the right was derived empirically from the bulk porosity model as described in the text. A possible subdivision into seismic Layers $2 \mathrm{~A}, 2 \mathrm{~B}$, and $2 \mathrm{C}$ is indicated. B. The observed sonic velocity (model OBS) profile for Hole 504B plotted alongside the preferred velocity profiles of Little and Stephen (1985) (dashed line) and Collins (1989) (heavy solid line), based on borehole and sonobuoy seismic-refraction data, respectively.

gional reconnaissance of the crustal reflectivity structure around the drill site. Shotpoint spacing was about $50 \mathrm{~m}$, and the 2.4$\mathrm{km}$-long receiver array consisted of 48 channels with a group separation of $50 \mathrm{~m}$. The MCS data were collected into 24-fold common-midpoint (CMP) gathers, with a CMP spacing of $25 \mathrm{~m}$.

For the study described here, attention was focused on the shallow crust only. In order to correlate the drilled lithologic sequence with possible intracrustal reflections in the MCS data, processing efforts were concentrated on short segments (15-25 $\mathrm{km}$ in length) of all five lines that pass near the drill site. In the following discussion, we present results for two of the five profiles, lines 485 and 490 . These profiles trend east to west and northwest to southeast, respectively (Fig. 1B). Both profiles were acquired with a four-element air gun array with chamber sizes of $235,350,500$, and 700 in. $^{3}(3.9,5.7,8.2$, and $11.5 \mathrm{~L})$, fired at a pressures of $2000 \mathrm{lb} / \mathrm{in}^{2}(13.8 \mathrm{MPa})$.

Processing of the MCS data included three different sequences designed to reduce noise resulting from diffractions from the irregular seafloor. The three sequences consisted of the following: (1) transformation of the shot records into CMP gathers followed by velocity analysis and CMP stack; (2) frequency-wavenumber $(f-k)$ filtering of the shot gathers, followed by CMP gather and CMP stack; and (3) transformation of the filtered shot gathers into receiver gathers, followed by $f-k$ filtering, CMP gather, and CMP stack.

The $f-k$ filtering of the shot and receiver gathers was prompted by the presence of arrivals in the shot records that were reflected from the sediment/basement interface both in front of and behind the receiver and also from outside the vertical plane defined by the source and receiver (Fig. 3). When transformed into CMP gathers (Fig. 4), such scattered phases have moveouts similar to intracrustal reflection events (e.g., Larner et al., 1983). For the MCS data acquired at Hole 504B, some of the scattered noise can be attenuated by applying an $f-k$ filter to the shot gathers. However, those parts of the scattered phases with small moveout (e.g., hyperbola apexes) cannot be attenuated without

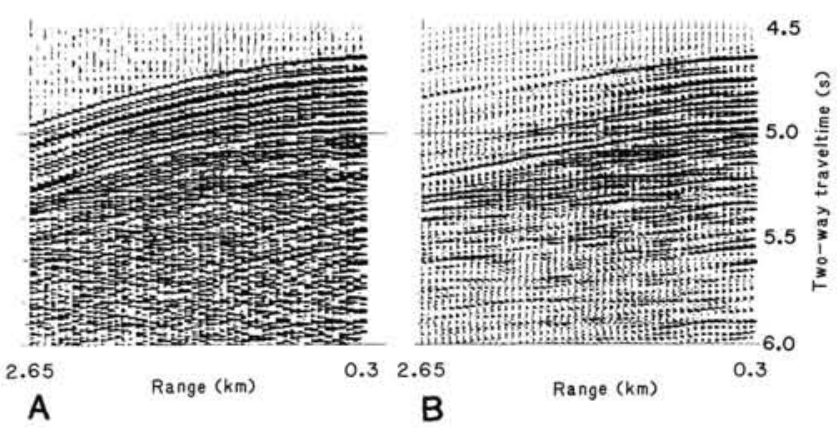

Figure 3. A. Shot gather 2489 from MCS line 485 , acquired about $5 \mathrm{~km}$ from the drill site. The seismograms are unfiltered. Amplitudes are multiplied by an exponential, time-varying function. The time window over which the time-varying gain function was applied ranges from 4.5 to $6.0 \mathrm{~s}$; the gain at $6.0 \mathrm{~s}$ is $40 \mathrm{~dB}$. Note the hyperbolic-shaped noise phases. These side-scattered phases are repeated at about 0.1 -s intervals, implying that the side-scattered energy is multiply reflected/refracted in the sedimentary section. This type of coherent noise is typical of all the MCS data. B. As for Figure 3A, but an $f-k$ filter designed to attenuate arrivals with moveouts of $6 \mathrm{~ms} /$ trace and greater was applied to the shot gather. Note that parts of the side-scattered phases were attenuated. The $f-k$ filter removes much of the seafloor reflection at greater offsets; however, it cannot remove the energy falling along the apexes of the hyperbolas. Aliased energy, arriving before the seafloor reflection, was introduced by the $f-k$ filtering.

also attenuating intracrustal events (e.g., Fig. 3). Simple calculations show that the moveout of these components of the scattered arrivals may increase when the data are transformed into receiver gathers. Accordingly, we regathered the previously filtered shot records into receiver gathers and again applied an $f-k$ filter. A drawback of $f-k$ filtering is the introduction of numerical phases with wavenumbers equal to the cutoff values of the filter, despite the use of a tapered band-pass window (Fig. 3). 


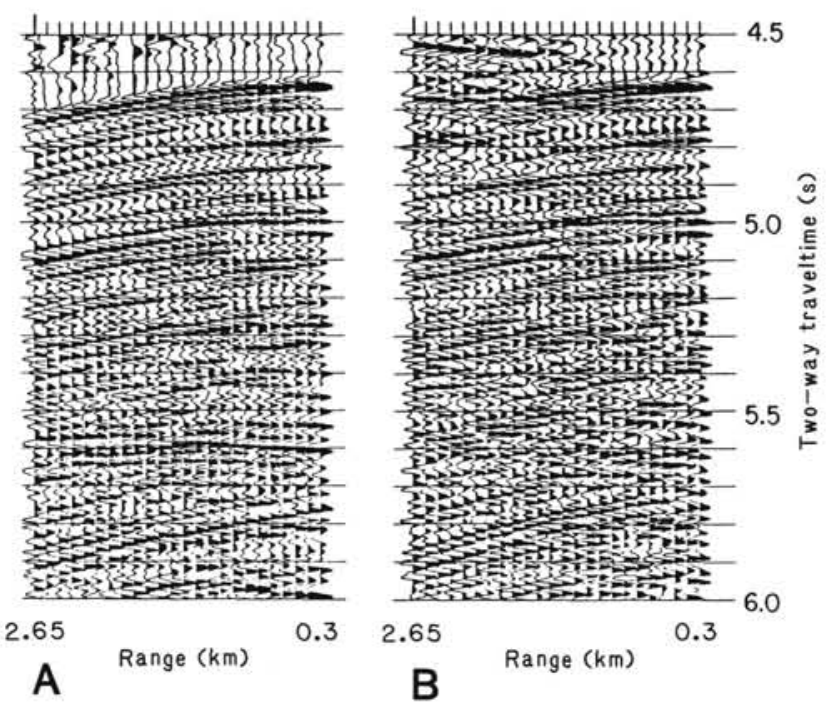

Figure 4. A. CMP gather 5000 from MCS line 490, acquired about $4 \mathrm{~km}$ from the drill site. The seismograms are unfiltered. Amplitudes are scaled using an automatic gain control (AGC) window of $0.25 \mathrm{~s}$. A normal-moveout (NMO) correction corresponding to a stacking velocity of $1.8 \mathrm{~km} / \mathrm{s}$ was applied to the data. Consequently, all of the phases that dip from right to left have stacking velocities less than this value. The horizontally-directed phase at $5.6 \mathrm{~s}$ has a stacking velocity of $1.8 \mathrm{~km} / \mathrm{s}$, anomalously low for a reflection event with a crustal traveltime of $0.7 \mathrm{~s}$. B. As for Figure $4 \mathrm{~A}$, but an $f-k$ filter was applied to the shot gather prior to CMP gather. The 5.6-s event has been attenuated, implying that this event is a side-scattered phase.

For the MCS data collected at Hole 504B, any positive effects of applying the second $f-k$ filter appeared to have been outweighed by the introduction of additional spatially-aliased arrivals.

We attempted to optimize the stacking velocities using two approaches. We plotted CMP gathers every 1-2 km, and applied normal-moveout (NMO) corrections appropriate for a range of velocities increasing from 1.4 to $2.1 \mathrm{~km} / \mathrm{s}$, in intervals of $0.1 \mathrm{~km} / \mathrm{s}$, to each gather. In addition, the CMP gathers were stacked at constant velocities of $1.4-2.1 \mathrm{~km} / \mathrm{s}$, in intervals of $0.1 \mathrm{~km} / \mathrm{s}$, to generate constant-velocity stacks.

Constant-velocity stacks of a part of line 490 are shown in Figures 5 and 6 . The shallow-crustal reflection events in the profile showing the data stacked with a velocity of $1.5 \mathrm{~km} / \mathrm{s}$ (Fig. 5) probably represent source reverberation and sediment-column multiples. The "tails" of some of the diffraction hyperbolas evident in Figure 5A are attenuated in the $f-k$-filtered data shown in Figure 5B. Many of the reflection events evident in Figure 5 are not seen in the data stacked with a velocity of $1.8 \mathrm{~km} / \mathrm{s}$ (Fig. 6 ). The sonic velocity log collected at Hole 504B predicts that this value is the appropriate stacking velocity for a reflection event from the volcanic/dike contact. The crustal traveltime of this predicted event is $0.25 \mathrm{~s}$. Accordingly, the reflection event with a traveltime of 5.25-5.3 s (Fig. 6) may be a reflection from this lithologic boundary.

Parts of lines 490 and 485 , stacked with depth-varying velocities, are shown in Figures 7 and 8. Stacking velocities were calculated from the velocity-depth model derived from analysis of wide-angle reflection/refraction data collected at the drill site (Collins, 1989). This velocity-depth model predicts that a stacking velocity of about $1.9 \mathrm{~km} / \mathrm{s}$ is appropriate for a reflection event with an intracrustal traveltime of $0.25 \mathrm{~s}$. Both profiles show a reflection event with an intracrustal traveltime of $0.25-$ $0.3 \mathrm{~s}$. This event is the same as the event identified in the constant-velocity stacked section (Fig. 6). The traveltime and stacking velocity of this phase are consistent with it being a reflection from the volcanic/dike transition (Figs. 7 and 8). However, the constant crustal traveltime of this event is indicative of source reverberation or a "peg-leg" multiple generated within the sedimentary section. This latter interpretation is supported by the lack of evidence for a reflection event in the CMP gathers with a stacking velocity greater than or equal to $1.8 \mathrm{~km} / \mathrm{s}$ (Fig. 4). A relatively high-amplitude reverberation or multiple might not be completely attenuated by the CMP stack. The 5.25-5.3-s reflection event can also be seen in the data stacked with a velocity of $1.5 \mathrm{~km} / \mathrm{s}$ (Fig. 5).

\section{SYNTHETIC SEISMOGRAM MODELS FOR HOLE 504B}

The difficulty in identifying shallow-crustal reflection events may simply be due to the presence of high-amplitude, side-scattered arrivals. However, synthetic reflection seismograms calculated for a series of velocity-depth models constructed from the logged variations in physical properties at Hole 504B suggest that reflections from the shallow crust might be difficult to confidently identify even in the absence of noise.

\section{Impedance Models}

At Hole 504B, the seismic impedance of the upper crust is readily determined from downhole measurements of sonic velocity and density (e.g., Salisbury et al., 1985). However, the usefulness of these impedance values is uncertain because they represent averages over length scales of less than about $3 \mathrm{~m}$ (e.g., Salisbury et al., 1985) and consequently may not be representative of impedance variations at the seismic length scales of tens of meters appropriate for the MCS data. A simple average of these impedance values is probably inappropriate because the logged data are not necessarily indicative of velocity variations away from the drill hole. The velocity and density of the upper crust at seismic length scales can be estimated from the bulk porosity data, which are in turn estimated from the results of a large-aperture resistivity experiment (Becker, 1985). Although these relationships are not unique, the range of velocity-depth profiles presented below probably bounds the true values. The following argument assumes that velocity is a function of porosity only.

Bulk porosity $(\phi)$ and resistivity can be empirically related via Archie's law $r_{m} / r_{f}=a \phi^{-n}$, where $r_{m}$ and $r_{f}$ are the resistivity of the rock medium and pore fluid, respectively, and $a$ is a constant (Archie, 1942; Hyndman and Drury, 1976). The value of the exponent $n$ is a function of void geometry (Becker, 1985). The appropriate value of $n$ in oceanic crust ranges from 1.5 to 2.5 , with the lower values characteristic of cracks and the higher values characteristic of grain-boundary porosity (e.g., Becker, 1985). For Hole 504B, the nature of the porosity changes with depth, and consequently no one value of the exponent $n$ is appropriate (Salisbury et al., 1985).

The correlation of velocity with porosity is not unique because the velocity of a porous medium is dependent on void geometry (e.g., Watt et al., 1976). However, irrespective of void size and shape, the velocity bounds on an isotropic $n$-phase aggregate can be calculated using the method described by Hashin and Shtrickman (1963). The Hashin-Shtrickman velocity bounds on a water-rock aggregate are shown in Figure 9; the $P$ and $S$-wave velocities of the rock phase $(\mathrm{V} p=6.4 \mathrm{~km} / \mathrm{s}, \mathrm{V} s=$ $3.5 \mathrm{~km} / \mathrm{s}$ ) are the values predicted by the best-fit relationship between laboratory-measured values of velocity and porosity for samples recovered from Hole 504B (Salisbury et al., 1985). The density of the rock phase $\left(2.94 \mathrm{~g} / \mathrm{cm}^{3}\right)$ is that predicted by low-porosity $(0.1 \%)$ samples recovered from the bottom of Hole 504B (Christensen and Salisbury, 1985).

Velocity and porosity can also be related via the self-consistent scheme (SCS), which allows the calculation of velocity as- 


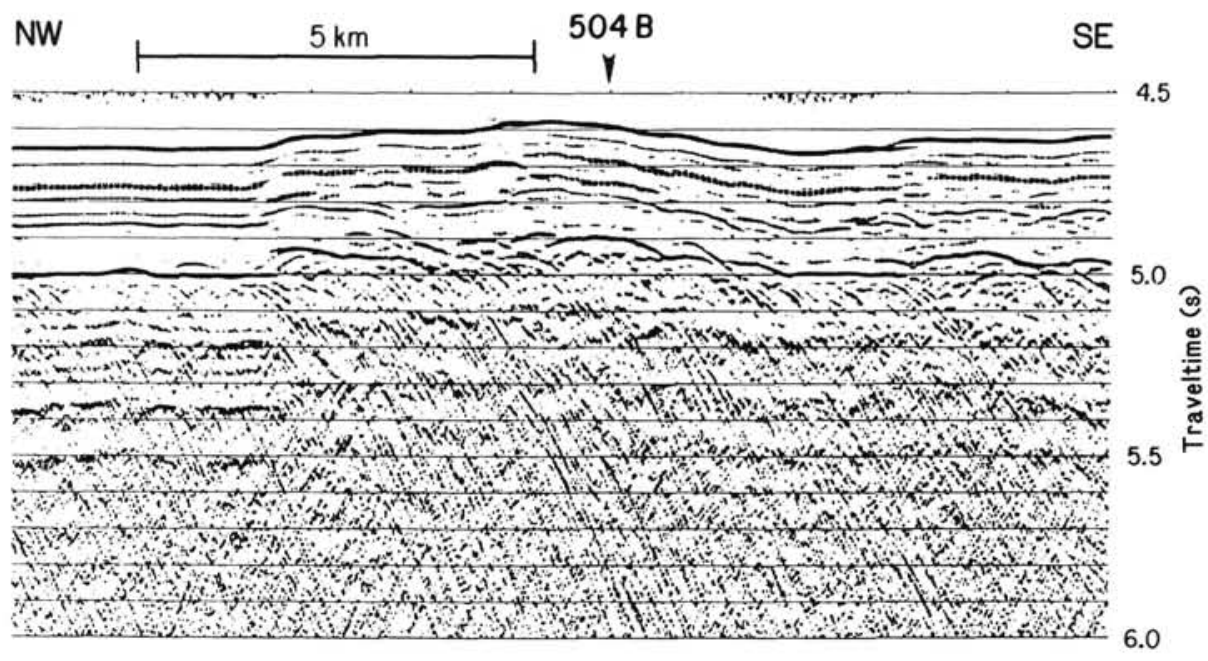

490

A

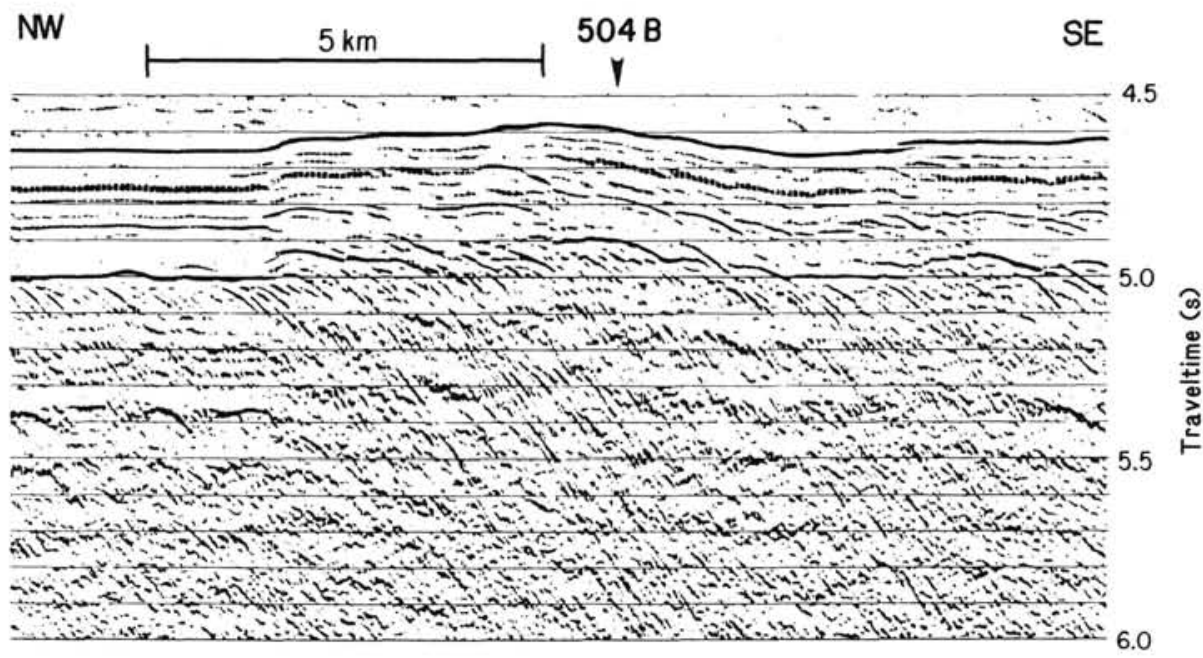

490

B

Figure 5. A. Part of MCS line 490, stacked at a constant velocity of $1.5 \mathrm{~km} / \mathrm{s}$. From left to right, CMP numbers range from 4550 to 5100 . The data are unfiltered. Amplitudes are scaled using an AGC window of $0.25 \mathrm{~s}$. B. As for Figure $5 \mathrm{~A}$, but an $f-k$ filter was applied to the shot gathers prior to CMP sorting and stacking. The hyperbolic diffractions are reduced in amplitude.

suming interacting voids of specific shape (Hill, 1965). The SCS prediction for fluid-filled spheres is shown in Figure 9; the prediction for disc-shaped voids coincides with the Hashin-Shtrickman lower bound. Also shown in Figure 9 is the empirical porosity-velocity relationship (EMP) derived from laboratory measurements (Salisbury et al., 1985).

The lack of correlation between measured permeabilities and the resistivity-derived porosities in Layer 2B and below may be explained by alteration products sealing an originally porous and permeable formation. Thus, by using resistivity-derived porosity estimates to infer seismic velocity, the velocities in the lower part of the hole may be underestimated. Therefore, we have used four paths through the velocity-porosity space appropriate to the rocks recovered from Hole 504B, together with the porosity-depth data, to calculate velocity-depth profiles from the bulk porosity data (Fig. 10). For each path, three velocitydepth profiles are presented, corresponding to different values of the exponent in Archie's law. The bulk porosity of the upper $53 \mathrm{mbsf}$ was assumed equal to the value at a depth of $3787 \mathrm{~m}$ below sea level, where the first resistivity measurement was made (Becker, 1985). The downhole variation in the density of the igneous crust is readily calculated from the density of the rock matrix and the bulk porosity.

Many of the synthetic seismograms shown here were calculated from the two velocity-depth models illustrated in Figure 2A. Model OBS is taken from the observed sonic-velocity data averaged into layers 10-m-thick. Model EMP20 (also referred to as EMP) is derived from the porosity-depth log using an empirical relationship for porosity and velocity (Salisbury et al., 1985). The 20 in EMP20 indicates that an Archie's law exponent of 2.0 was used to convert resistivity values to porosities. With the exception of the chert layer, the velocity and density of the sedimentary sequence for both models OBS and EMP20 are the laboratory-measured values of Wilkens and Langseth 


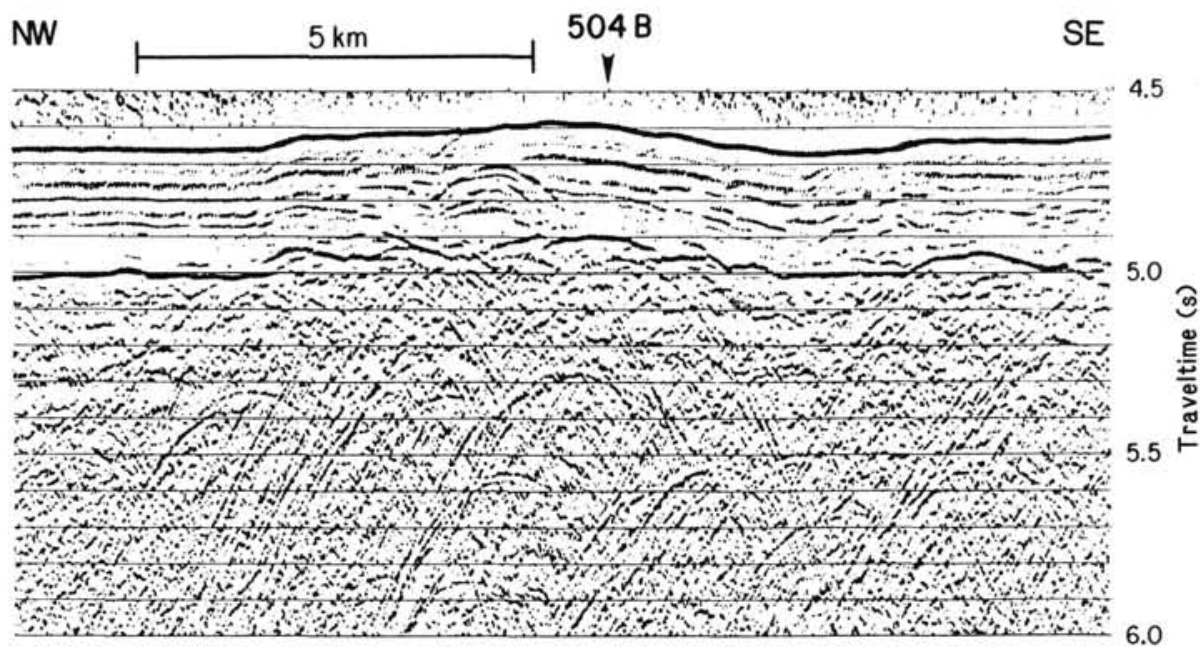

490

A

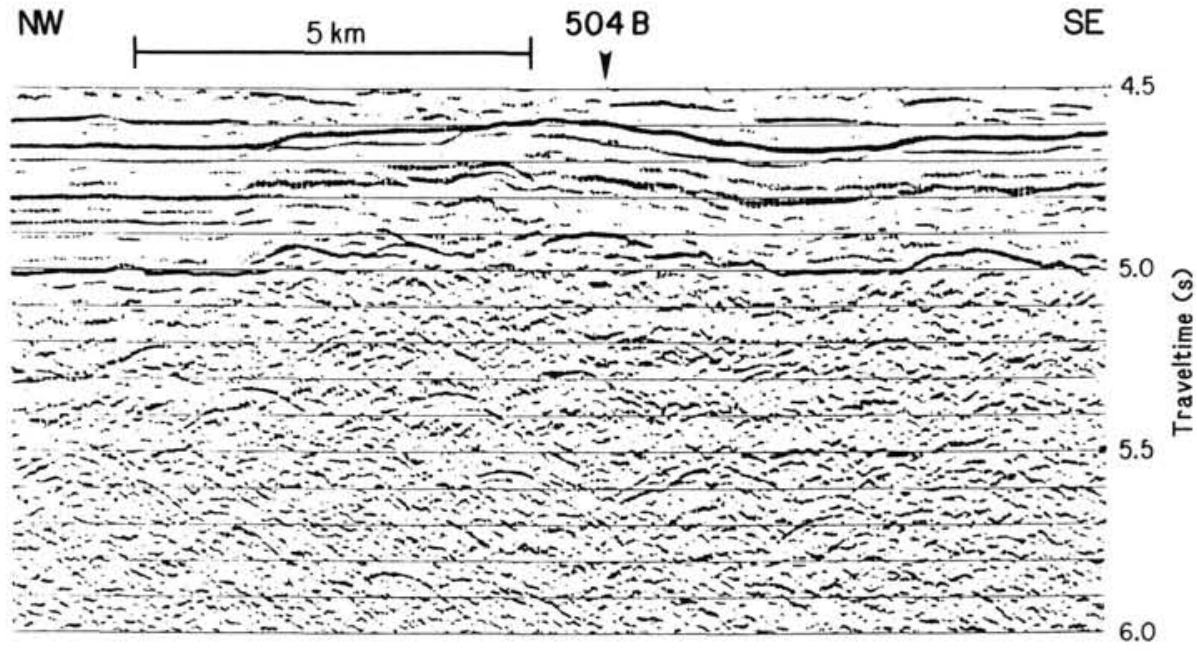

490

B

Figure 6. A. Part of MCS line 490, stacked at a velocity of $1.8 \mathrm{~km} / \mathrm{s}$. CMP numbers are as given in Figure 5. The data are unfiltered, and the amplitudes are scaled using an AGC window of $0.25 \mathrm{~s}$. B. As for Figure 6A, but an $f-k$ filter was applied to the shot gathers prior to CMP sorting and stacking. The hyperbolic diffractions are reduced in amplitude.

(1983). The velocity of the sedimentary section is close to 1.5 $\mathrm{km} / \mathrm{s}$. The density of the chert sequence was assumed to be 2.2 $\mathrm{g} / \mathrm{cm}^{3}$, typical of reported values (Hamilton, 1978).

\section{Normal-Incidence Synthetic Seismograms}

Normal-incidence synthetic seismograms were calculated with a frequency-domain reflectivity code (Berryman et al., 1958) and include all multiply-reflected phases. The layers of the input models were assumed to be nonattenuative. The signatures and spectra of the source functions used to calculate the seismograms presented here are shown in Figure 11. Source LDGO is the source signature (manufacturer's specification) of the 1785in. ${ }^{3}(29.3-\mathrm{L})$ air gun array used to acquire the MCS data. The tuned source is a 4170 -in. ${ }^{3}(68.3-\mathrm{L})$ air gun array described by Brandsaeter et al. (1979), chosen because it is representative of a well-tuned source array having a high primary-to-bubble ratio.
Comparison of the normal-incidence seismograms presented in either Figure 12 or 13 demonstrates that both sediment-column and internal multiples contribute significantly to the computed seismogram. As shown in the presentation of velocity models as a function of traveltime in Figure 10, no primary phases are predicted at times greater than about $5.4 \mathrm{~s}$. Given realistic attenuation values, the amplitude of these multiple events would be attenuated. Seismic attenuation values for the rock types (oozes and chalks) that constitute the sedimentary section at Hole 504B have not been reported in the literature. However, assigning attenuation values of $0.01-0.005 \mathrm{~dB} / \mathrm{m}$ to the sedimentary sequence does not significantly affect the amplitude of the multiply-reflected events. These attenuation values, corresponding to seismic Q values of 72 and 144, are typical of a fine-grained sedimentary rock (Hamilton, 1972, 1976). The importance of multiply-reflected arrivals is evident on inspection of the observed data in Figure 5. 


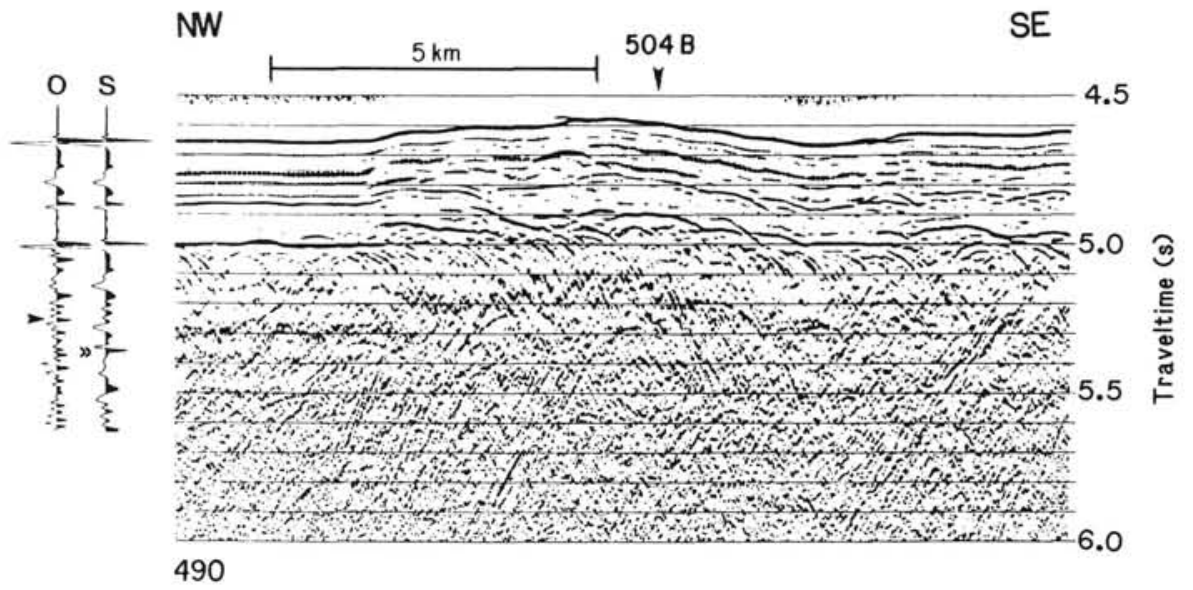

Figure 7. CMP-stacked seismograms for MCS line 490. CMP numbers are as given in Figure 5. Stacking velocities were determined from velocity analysis of wide-angle reflection/refraction data collected in the immediate vicinity of the drill site. The unfiltered seismograms are scaled with an AGC window of $0.25 \mathrm{~s}$ duration. The seismograms to the left of the stacked profile are synthetic normal-incidence seismograms computed using model OBS (Fig. 2A). Seismogram O was computed for the sedimentary and igneous sections of model OBS whereas seismogram S was computed for only the sedimentary section of the model. The single arrow shows the reflection event generated at the volcanic/dike boundary; the double arrow indicates the primary sediment-column multiple. For seismogram S, the phases between the basement reflection phase and the primary multiple represent source reverberation and the peg-leg multiple generated within the sedimentary section. The source pulse used to compute the seismogram is that for the air gun array used to acquire the CMP data. The synthetic seismograms are scaled in an identical manner to the observed data and were filtered at 5-60 Hz.

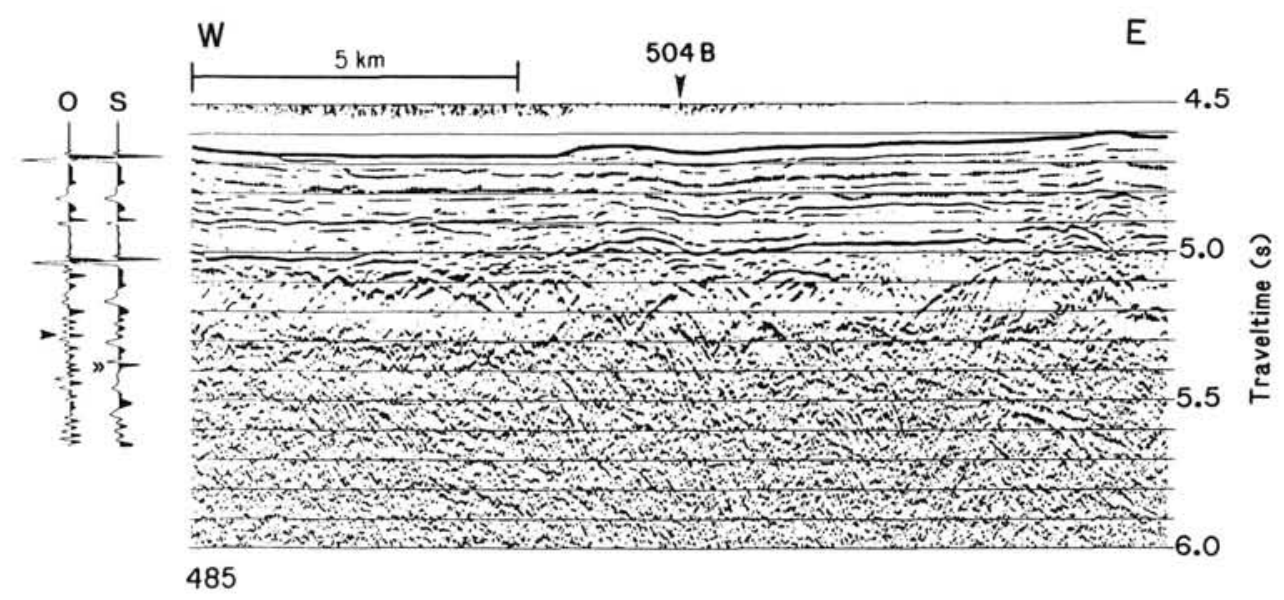

Figure 8. CMP-stacked seismograms for MCS line 485. From right to left, CMP numbers range from 7400 to 8000 . The data and synthetics are stacked and scaled as described in Figure 7.

The most readily recognized reflection event is seen at $5.35 \mathrm{~s}$ (Figs. 12 and 13) and is generated in the vicinity of the Layer 2/ Layer 3 transition (Fig. 2B). However, the sonic velocity logs may be unreliable at these depths because these data were acquired close to the bottom of the drill hole. At shallower depths, the reflection event at $5.2 \mathrm{~s}$ (Figs. 12 and 13) correlates best in time and depth with the volcanic/dike boundary. This event has a greater amplitude in the seismogram calculated for the observed velocity-depth profile than in the seismogram calculated for the velocity-depth model without the sedimentary section. This is probably due to the reduced impedance contrast at the sediment/basement interface in the former model. The 5.2-s re- flection event has a traveltime that is only $0: 25 \mathrm{~s}$ greater than the basement reflection event and consequently, is obscured by the source reverberation of the basement reflection event in the seismograms calculated with source LDGO (Fig. 12). Without accurate source deconvolution, the 5.2-s event might be difficult to distinguish from source reverberation in observed data. This event is more readily recognized in the seismograms calculated with the signature of the tuned array. Reflections generated from within the volcanic sequence are also identifiable in the latter seismograms. The synthetic seismograms calculated for the velocity-depth profiles derived from the velocity-porosity relationships shown in Figure 9 are clearly dominated by source 


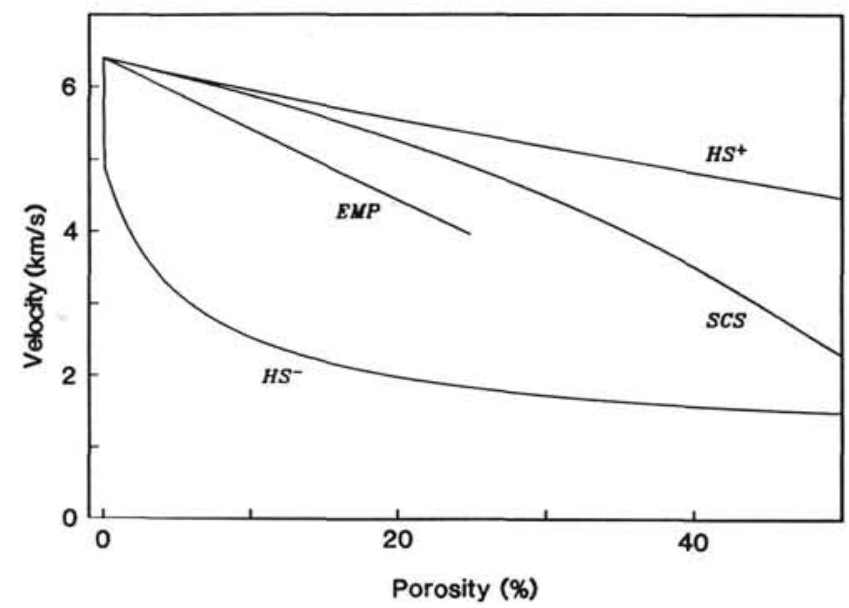

Figure 9. Possible porosity-velocity relationships for Hole 504B calibrated to the physical properties of samples recovered at Hole 504B. Curves $\mathrm{HS}^{+}$and $\mathrm{HS}^{-}$represent the Hashin-Shtrickman upper and lower bounds on velocity-porosity space, curve SCS is the relationship predicted by the self-consistent scheme (see text), and curve EMP is the empirical relationship between laboratory-measured values of velocity and porosity (Salisbury et al., 1985). These curves were calculated using the formulae presented in Watt et al. (1976).

reverberation and sediment-column multiples (Fig. 14). Only velocity-depth profile $\mathrm{HS}^{-}$generates a readily recognized reflection event (Fig. 14B).

\section{Synthetic CMP Gathers}

The normal-incidence synthetic seismograms of Figures 1214 are not strictly analogous to the seismograms of MCS data that are generated by stacking tens of seismograms having a common midpoint. Layer boundaries with low seismic impedance may be more readily detected by recording arrivals at horizontal ranges close to the $P$-wave critical point where the amplitudes of the reflected phase are significantly greater than at normal incidence. Accordingly, we attempted to better replicate the CMP stacking method by calculating and stacking synthetic CMP gathers (Figs. 15A and 16A) for velocity models OBS and EMP20 (Fig. 2A) using the reflectivity method (Fuchs and Muller, 1971; Kennett, 1975). Synthetic CMP gathers for the range window $0.3-2.7 \mathrm{~km}$ were summed using stacking velocities calculated from the input velocity models. These gathers were computed for frequencies of $10-30 \mathrm{~Hz}$ because comparison of filtered and unfiltered samples of the observed MCS data demonstrates that the observed data have negligible energy at frequencies greater than $30 \mathrm{~Hz}$. The 5.2 -s reflection event in the stacked CMP gather calculated for model OBS (Fig. 15B) correlates with the volcanic/dike boundary. However, this event is difficult to distinguish from source reverberation. The stacked CMP gather (Fig. 16B) computed for model EMP20 does not show a readily identifiable event from this geological boundary. Comparison of Figures 15A and 16A with Figures 12-14 suggests that a receiver array with an aperture greater than $2.4 \mathrm{~km}$ would not necessarily increase the amplitude of the 5.2-s event. At ranges greater than $2.7 \mathrm{~km}$, synthetic CMP gathers for both the OBS and EMP20 models are dominated by refracted arrivals.

In the reflectivity method, the Fourier transform of the pressure response at the receiver is represented by a Hankel transform over the incidence angle of the product of the reflectivity function and Bessel functions of the first kind. Stephen (1977, 1983) showed that for accurate seismogram calculation the lim- its of integration of the Hankel transform must be chosen wide enough to avoid the introduction of false arrivals with phase velocities corresponding to one or other of the integration limits. In addition, the angle increment must be sufficiently small so that the computed seismograms do not show reverberative noise (Stephen, 1977, 1983; Mallick and Frazer, 1987).

For the velocity structures of interest in this paper, the minimization of the noise sources described in the preceding requires excessive computation. The synthetic CMP gathers shown in Figures $15 \mathrm{~A}$ and $16 \mathrm{~B}$ were computed using an angle increment of $0.023^{\circ}$ and integration limits of $0.07^{\circ}$ and $40^{\circ}$. These limits correspond to phase velocities of 1100 and $2.175 \mathrm{~km} / \mathrm{s}$, respectively. This choice of parameters introduces a high-amplitude numerical arrival with a phase velocity of $2.175 \mathrm{~km} / \mathrm{s}$, but results in negligible reverberative noise. The false arrival has a negligible effect on the seismograms included in the CMP stack.

In implementing the reflectivity method used to compute the synthetic CMP gathers shown in Figures 15A and 16B, the Bessel functions in the integrand of the Hankel transform are approximated by Hankel functions. This approximation is satisfactory when the argument of the Bessel function is greater than 15 for those values of frequency and incidence angle that contribute most to the integrand (Stephen, 1977). When the approximation is inappropriate, values of the reflectivity function at large angles of incidence are weighted more heavily than they should be. For the synthetic CMP gathers shown here, the minimum value of the Bessel function argument is about 0.15 . To check the accuracy of these calculations, we computed synthetic seismograms for which the Bessel functions were alternately approximated by Hankel functions and by Chebyshev polynomials. The latter are a better approximation than the former when the argument of the Bessel function is small. For horizontal ranges of $0.3-3.0 \mathrm{~km}$ using the incidence angles and frequencies listed in the preceding, the seismograms for both of these approximations were not observably different.

\section{Wide-Aperture Synthetic CMP Gathers}

Synthetic reflection modeling at normal incidence shows that the smooth velocity transition that characterizes the velocity profiles derived from estimates of the bulk porosity data are dominated by source reverberation and sediment-column multiples (Fig. 14). However, wide-aperture synthetic CMP gathers for model EMP20 (Fig. 2A) show that the velocity gradient, which defines the volcanic/sheeted dike transition, generates high-amplitude refracted arrivals at horizontal ranges of 6-7 km (Fig. 17A). These seismograms were calculated using an angle increment of $0.051^{\circ}$ and integration limits of $0.17^{\circ}$ and $89^{\circ}$, corresponding to phase velocities of 500 and $1.5001 \mathrm{~km} / \mathrm{s}$, respectively. In contrast to the seismograms presented in Figures $15 \mathrm{~A}$ and $16 \mathrm{~A}$, this choice of parameters does not introduce false arrivals but causes low-amplitude reverberative noise. However, this noise has negligible effect on the observed amplitude focusing at the $6-7-\mathrm{km}$ range.

The observation of high-amplitude refracted arrivals (Fig. 17) suggests that the depth to the extrusives/sheeted dike transition at Hole 504B might be more readily mapped with the wideangle reflection/refraction technique than with conventional MCS techniques. Wide-angle reflection/refraction data acquired at Hole 504B show amplitude focusing at ranges of 5-7 km (Collins, 1989), as predicted by the synthetic seismogram modeling. The horizontal range of this amplitude high has been shown to be a sensitive indicator of the depth to the Layer 2/ Layer 3 velocity transition (Bratt and Purdy, 1984). Accordingly, the Layer 2/Layer 3 boundary at Hole 504B must lie in the vicinity of the volcanic/dike transition. 


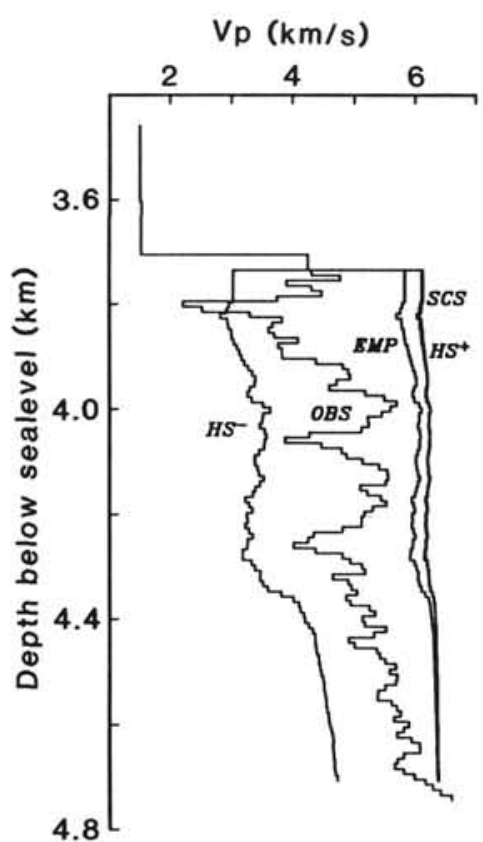

A

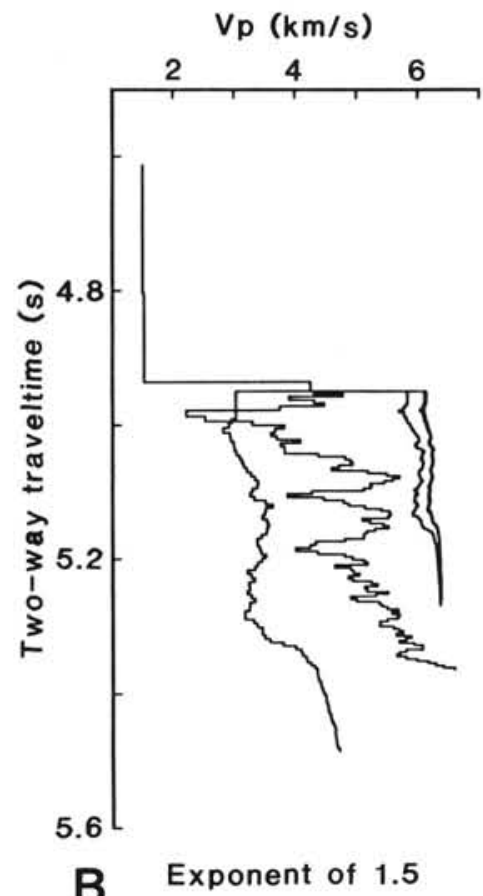

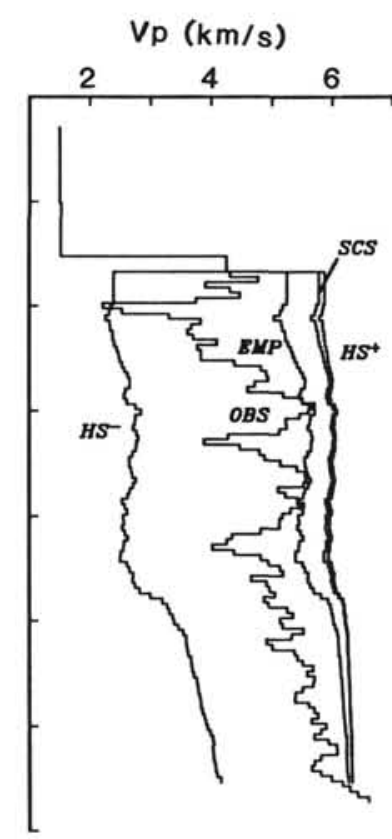

Exponent of 2.0

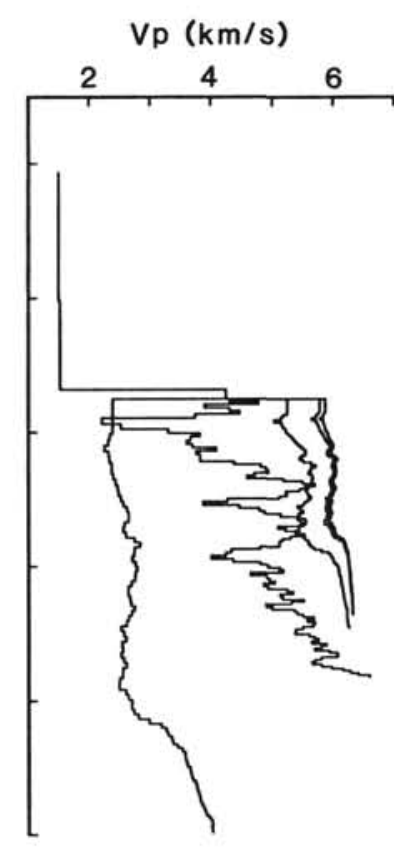

Exponent of 2.0

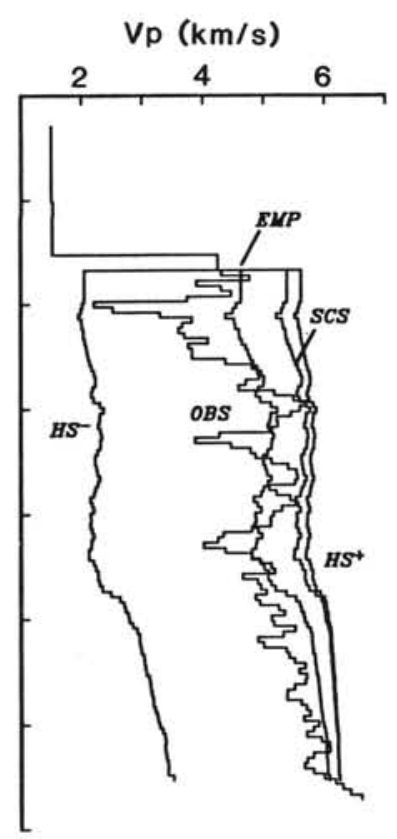

Exponent of 2.5

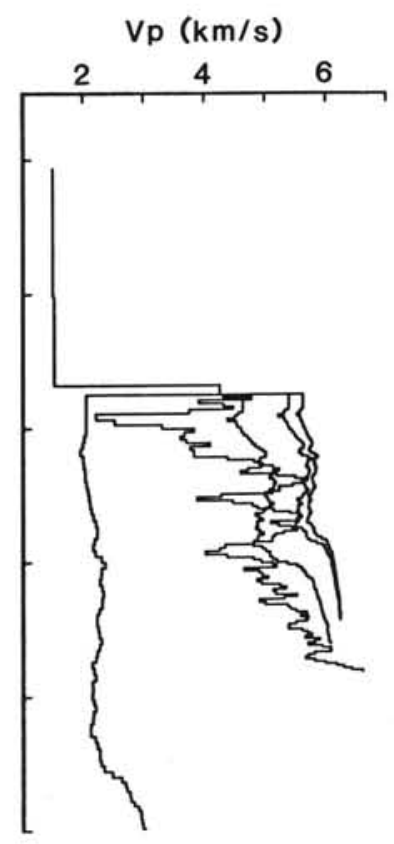

Exponent of 2.5

Figure 10. A. Velocity-depth profiles for Hole 504B. Model OBS is the observed sonic velocity data averaged into 10 -m-thick layers. The remaining models correspond to the velocity-porosity relationships illustrated in Figure 9 . With the exception of model OBS, all of the models are shown for three different values of the Archie's law exponent. B. Velocity-two-way-traveltime profiles corresponding to Figure 10A.

\section{DISCUSSION}

The difficulty in identifying a reflection event generated within the upper crust at Hole 504B is probably due to a combination of factors in the experimental technique and geological structure. The high-amplitude, side-scattered arrivals characteristic of the MCS data (e.g., Fig. 3) cannot be completely removed by $f-k$ filtering, and these events probably obscure intra- crustal reflections. Given this noise problem, the ability to confidently identify an intracrustal reflection event at Hole 504B would probably be improved if MCS data were acquired with a receiver array characterized by a shorter group separation. The shorter group separation would allow more accurate $f-k$ filtering, minimizing the effects of spatial aliasing. Side-scattered arrivals in MCS data acquired on the Juan de Fuca Ridge were successfully removed by $f-k$ filtering (Rohr et al., 1988). These 

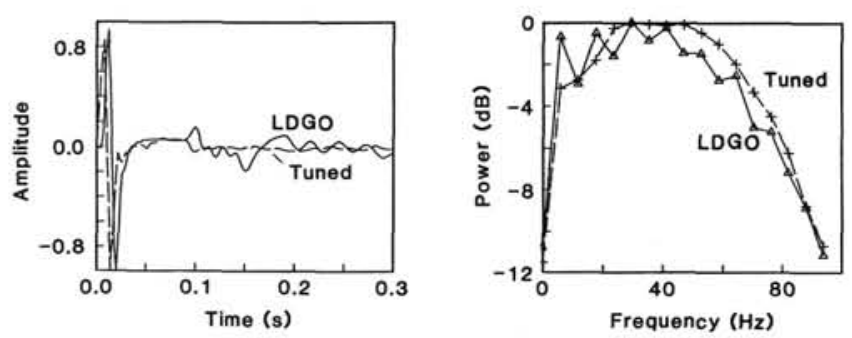

Figure 11. Source signatures and spectra of the two source pulses used to calculate synthetic seismograms. Although the spectra are similar, the primary-to-bubble pulse ratio of the tuned array is superior to the LDGO source.

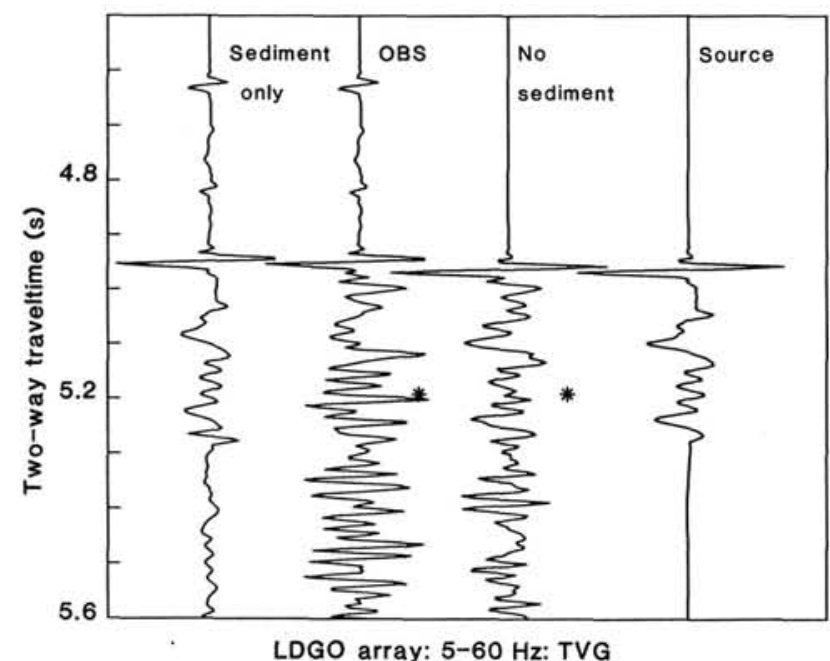

Figure 12. Normal-incidence reflectivity synthetic seismograms computed for only the sedimentary section of model OBS, both the sedimentary and igneous sections of model OBS, and only the igneous section of model OBS using source LDGO. The asterisks indicate the twoway traveltime to the top of the volcanic/dike boundary. Amplitudes have been multiplied by an exponential, time-varying function. The time window over which the time-varying gain (TVG) function was applied ranges from 5 to $5.5 \mathrm{~s}$; the gain at $5.5 \mathrm{~s}$ is $20 \mathrm{~dB}$.

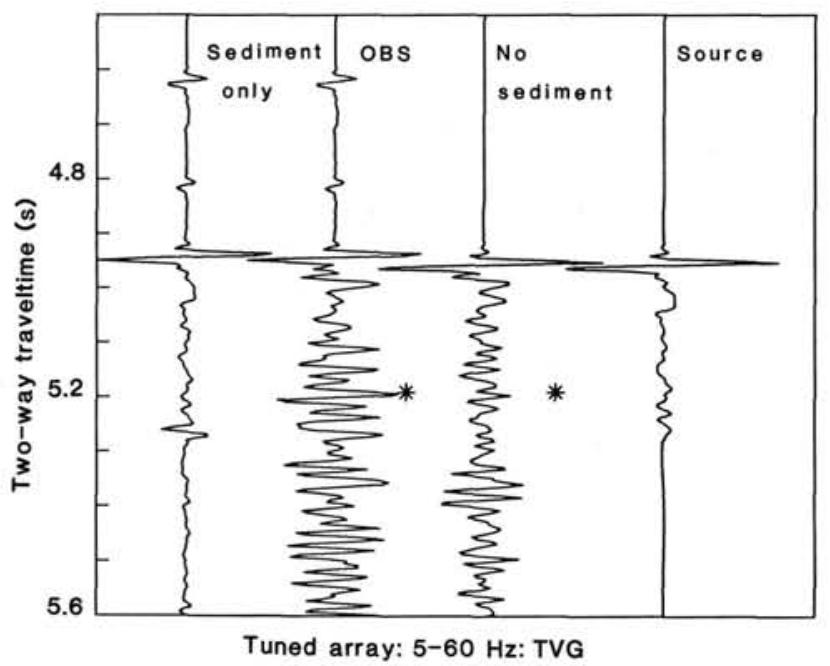

Figure 13. As for Figure 12, but the normal-incidence synthetic seismograms were computed with the tuned source function. This source has significantly greater resolution than source LDGO. The asterisks indicate the two-way traveltime to the top of the volcanic/dike boundary.
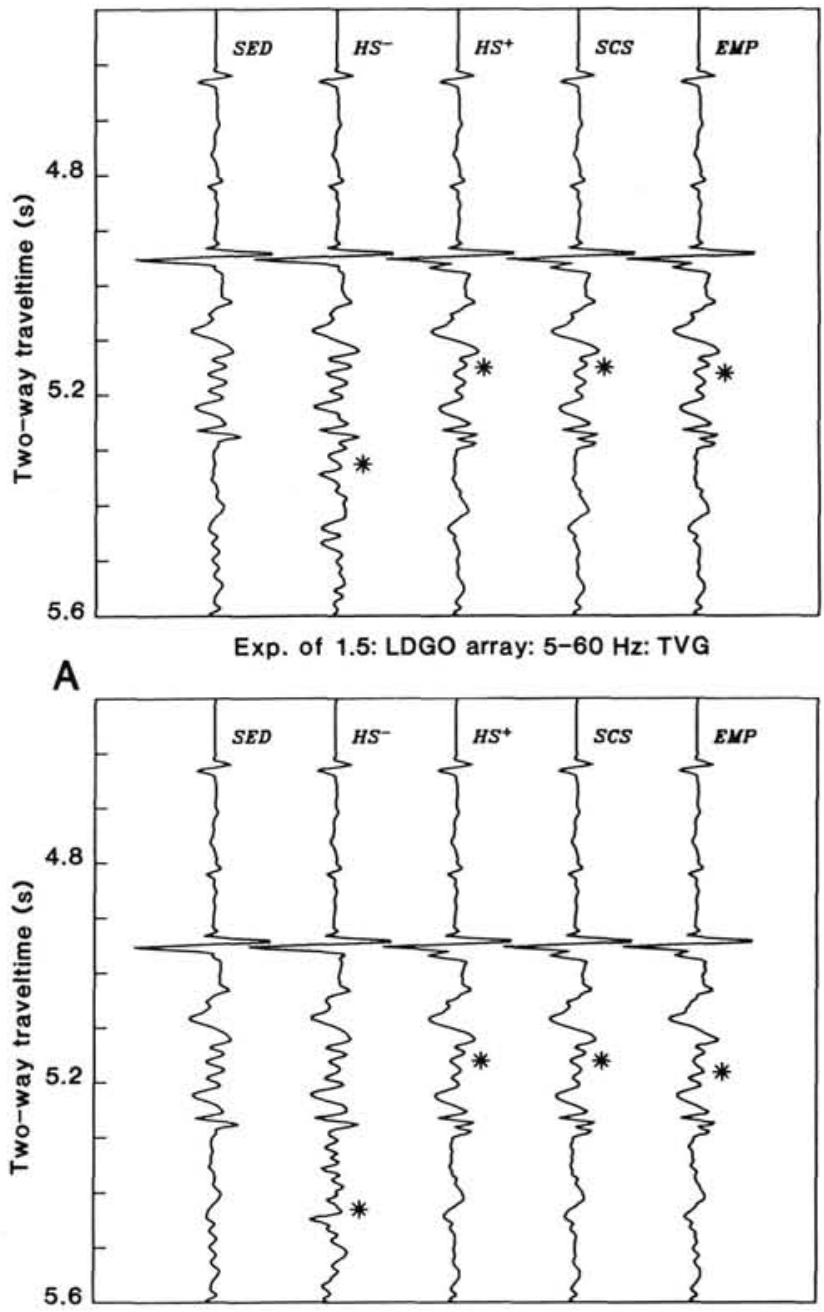

B

Exp. of 2.0: LDGO array: 5-60 Hz: TVG

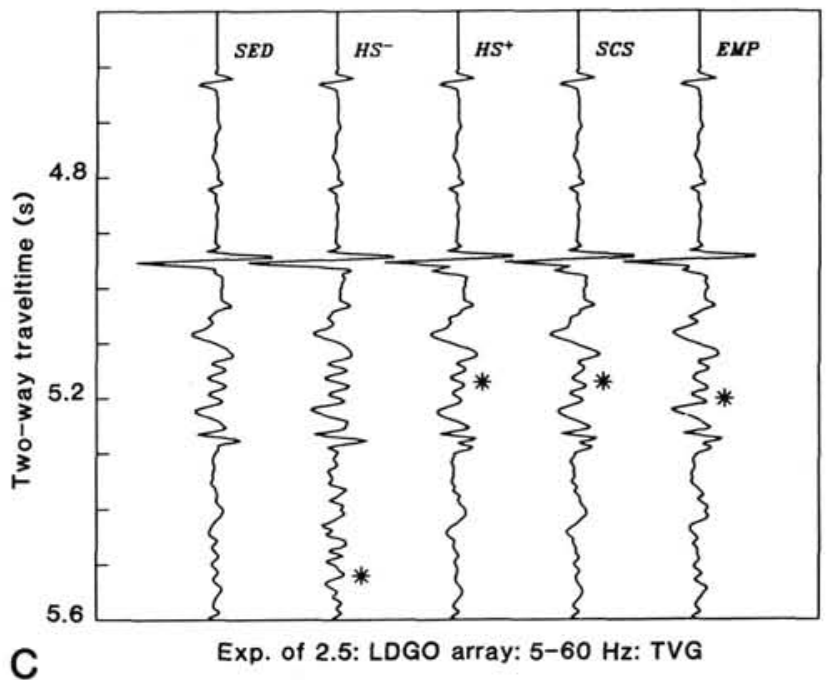

Figure 14. Normal-incidence synthetic seismograms for the velocitydepth models shown in Figure 10. The seismograms calculated for the porosity-derived velocity profiles are all similar to each other, indicating that they are dominated by the source reverberation and by multiply-reflected energy trapped within the sedimentary layer. The asterisks indicate the two-way traveltime to the top of the volcanic/dike boundary. Because of the variation of the Archie's law exponent with depth, seismograms were calculated for Archie's law exponents of (A) 1.5, (B) 2.0, and $(\mathbf{C}) 2.5$. 

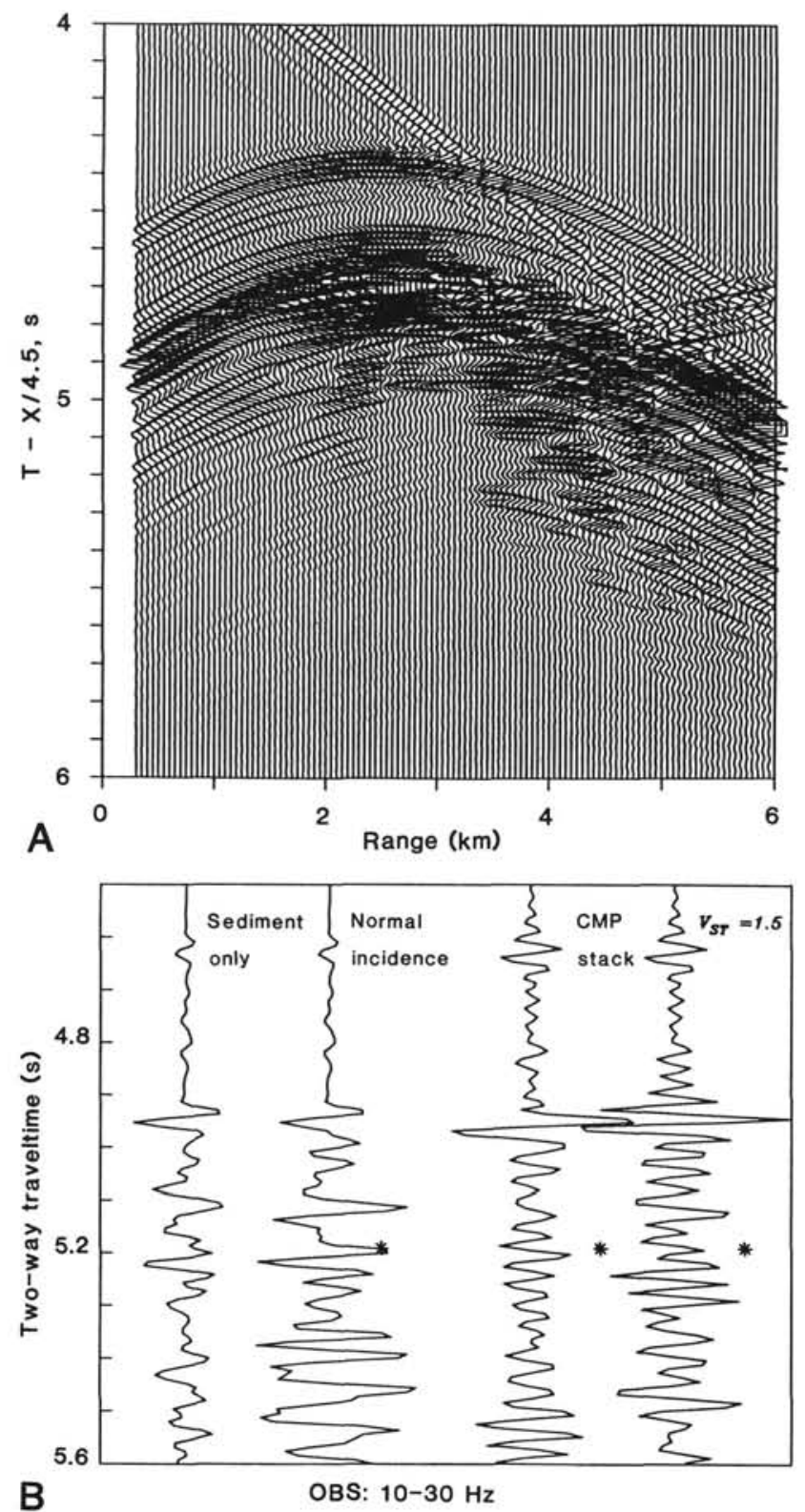

Figure 15. A. Synthetic CMP gather calculated for ranges of up to $6 \mathrm{~km}$ for velocity-depth model OBS (Fig. 2A). Amplitudes of the seismograms were multiplied by a constant scaling factor and plotted with a reduction velocity of $4.5 \mathrm{~km} / \mathrm{s}$. The linear phase preceding the seafloor reflection is numerical noise. B. Comparison of two normal-incidence seismograms on the left (for velocity model OBS, excluding and including the igneous section) with two seismograms resulting from a CMP stack of seismograms in Figure 15A for the range window 0.3-2.7 km. The stacking velocities used for the seismogram labeled "CMP stack" were calculated from the input velocity-depth model. A constant stacking velocity of $1.5 \mathrm{~km} / \mathrm{s}$ was used to obtain the seismogram on the far right in order to accentuate sediment-column multiples. The asterisks indicate the two-way traveltime to the top of the volcanic/dike boundary. Amplitudes were multiplied by an exponential, time-varying function. The time window over which the gain function was applied ranges from 5 to $5.5 \mathrm{~s}$; the gain at $5.5 \mathrm{~s}$ is $30 \mathrm{~dB}$. The amplitudes of the two normal-incidence seismograms are comparable, as are those of the CMP-stacked seismograms.

data, which show an intracrustal reflection event with a crustal traveltime of $0.3-0.55 \mathrm{~s}$ (Table 1), were acquired with a receiver array having a group separation of only $25 \mathrm{~m}$ (Rohr et al., 1988), as opposed to $50 \mathrm{~m}$ for the present study.
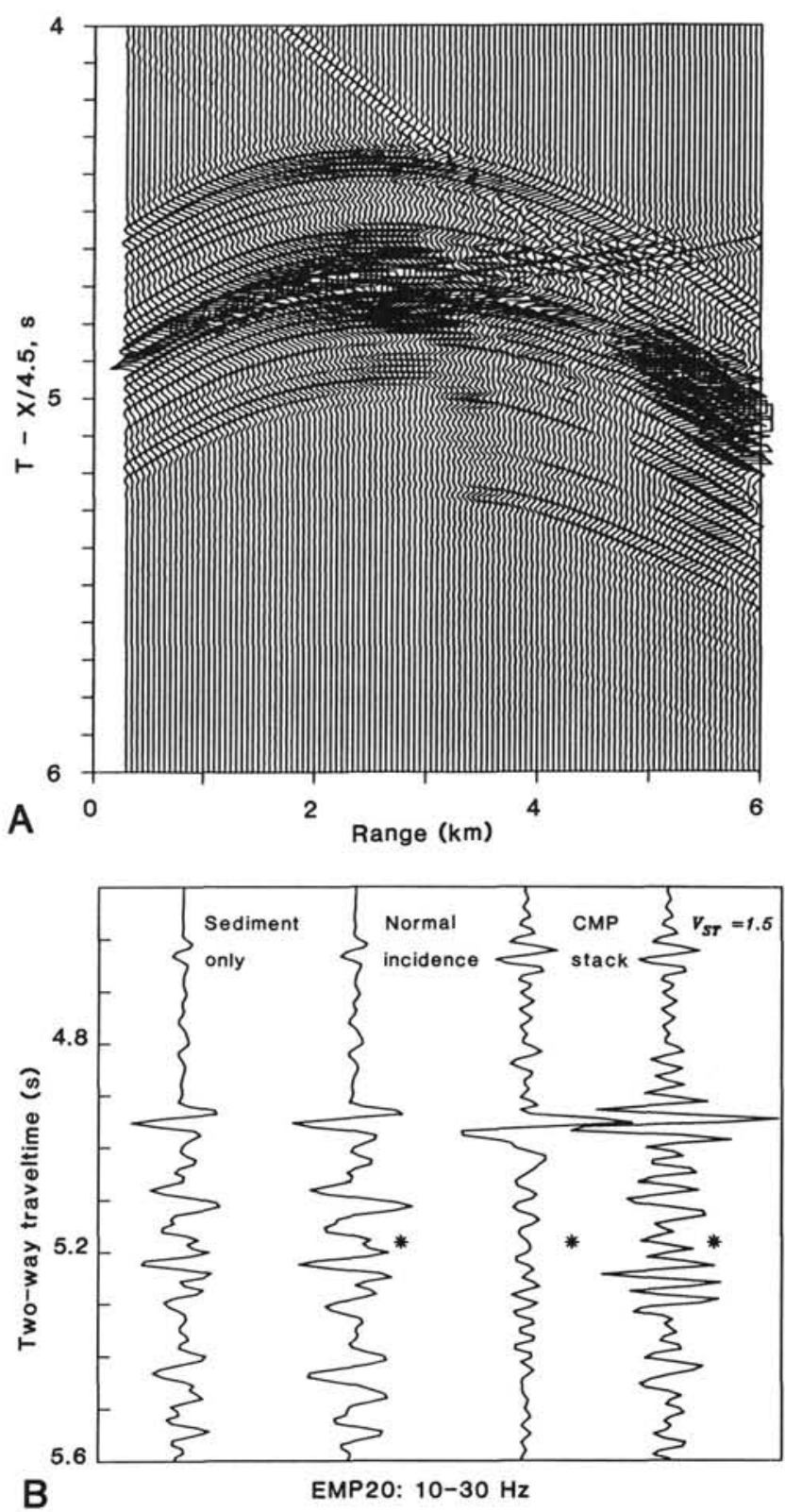

Figure 16. A. Synthetic CMP gather calculated for velocity-depth model EMP20 (Fig. 2A) and plotted as described for Figure 15A. B. Comparison of two normal-incidence seismograms on the left (for velocity model EMP20, excluding and including the igneous section) with two seismograms resulting from a CMP stack of the seismograms in Figure $16 \mathrm{~A}$ for the range window $0.3-2.7 \mathrm{~km}$. The asterisks indicate the twoway traveltime to the top of the volcanic/dike boundary. Amplitudes have been scaled as described in Figure 15B.

The synthetic seismograms shown in Figure 12 demonstrate that it would be difficult to assert that the 5.2-s event represents an intracrustal reflection rather than source reverberation without knowledge of the velocity-depth model and the source signature. This problem does not arise for the seismograms calculated with the shorter-duration source signature (Fig. 13). Clearly, accurate deconvolution of the MCS data using the measured source signature would aid in identifying a reflection event from the volcanic/dike boundary. We did not attempt to deconvolve the MCS data collected at Hole 504B because of lack of knowledge of the source signature. The signature shown in Figure 11 is only an approximation to the true signature. We did not use the seafloor reflection as an estimate of the source signature be- 

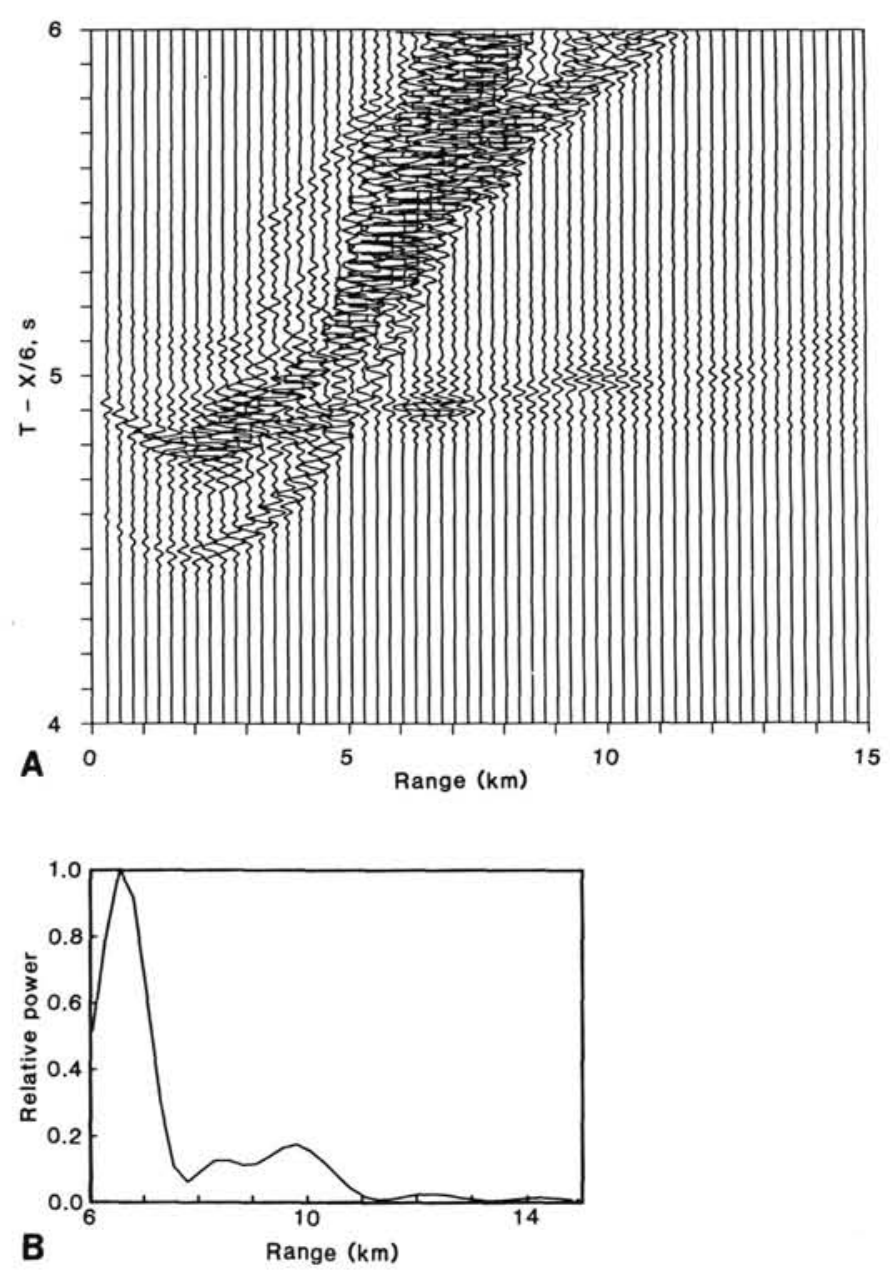

Figure 17. A. Wide-aperture synthetic CMP gather calculated for velocity-depth model EMP20 (Fig. 2A). Amplitudes were multiplied by a linear function of range, and times were plotted with a reduction velocity of $6.0 \mathrm{~km} / \mathrm{s}$. The velocity gradient corresponding to the volcanic/dike transition generates high-amplitude refracted arrivals at horizontal ranges of 6-7 km. B. Power vs. range for the seismograms shown in Figure 17A. The time window over which power was computed extends from 4.8 to $5.1 \mathrm{~s}$ reduced time. The power peak corresponds to the amplitude focusing observed at a range of 6-7 km.

cause inspection of the synthetic seismograms calculated with source LDGO (Fig. 12) shows that the seafloor reflection phase overlaps the reflection event generated at the sedimentary Unit 1/Unit 2 boundary. This event is also evident in the observed data (Figs. 7 and 8). The low amplitude of the 5.2-s event ensures that misidentification of the source pulse would prevent the accurate deconvolution required to image this event.

The side-scattered noise evident in the MCS data and the relative shallowness of the extrusives/sheeted dike boundary at Hole 504B clearly reduces the detectability of a reflection event from this horizon. However, it is also possible that the geological structure of the shallow crust at Hole 504B is anomalous relative to typical oceanic crust and differs from the crustal structure in those areas where high-amplitude shallow reflection events have been identified (Table 1). In the MCS data collected on the Juan de Fuca Ridge (Rohr et al., 1988), the reflection event from the shallow crust is of sufficient amplitude to be readily identifiable on the individual traces of CMP gathers (K.M.M. Rohr, pers. comm., 1988). While additional processing of the MCS data collected at Hole 504B might result in the imaging of a shallow reflection event, the amplitude of such an event is unlikely to be comparable to the high-amplitude event mapped on the Juan de Fuca Ridge. The effective impedance contrast across the geological structure generating this high-amplitude event must be much greater than the impedance contrast across the volcanic/dike boundary at Hole 504B.

The difference in the impedance structure of the Juan de Fuca and Hole 504B sites does not rule out the possibility that the event described by Rohr et al. (1988) was generated at a lithologic/porosity transition similar to that observed at Hole 504B. If the thickness of the volcanic/dike transition at Hole 504B was half of that observed, the effective impedance would be significantly enhanced. In the absence of any evidence to the contrary, and given supporting evidence from ophiolite studies, it is reasonable to suggest that the transition zone drilled at Hole 504B is a fundamental feature of the oceanic crust. The thickness of this transition zone controls the reflectivity structure of the upper crust and must vary over length scales of a few kilometers because the reflection amplitudes of the events listed in Table 1 vary laterally over this length scale (see references in Table 1). This inferred variation in transition zone thickness is consistent with the results of ophiolite mapping. These studies show that the depths and thicknesses of the volcanic/dike, dike/ gabbro, and metamorphic facies transition zones can vary by hundreds of meters over distances of a few kilometers (Casey et al., 1981). These geological boundaries are strong candidates for producing shallow crustal reflections.

The question remains whether or not there are systematic long-wavelength variations in the thickness of upper crustal transition zones which might explain regional differences in shallow crustal reflectivity. The limited available data set does not appear to conclusively identify such a trend. The sites listed in Table 1 are characterized by variable crustal ages and spreading rates. Crustal ages range from less than 1 m.y. (Juan de Fuca) to more than 100 m.y. (western North Atlantic), and halfspreading rates at the time of formation of these sites ranged from about $10 \mathrm{~mm} / \mathrm{yr}$ (western North Atlantic) to $30 \mathrm{~mm} / \mathrm{yr}$ (Juan de Fuca). The identification of systematic variations in upper crustal reflectivity as a function of seafloor-spreading parameters awaits the widespread acquisition of densely sampled MCS data using broad-band source arrays.

Although the relationship between shallow crustal reflections and the velocity structure of the upper oceanic crust remains to be determined, it seems plausible to correlate these reflections with the Layer 2/Layer 3 velocity transition zone. Bratt and Purdy (1984) have shown that the thickness of Layer 2 varies by up to $700 \mathrm{~m}$ over lateral distances of a few kilometers along a 0.5-m.y.-old, 200-km-long strip of crust on the East Pacific Rise. No systematic variations in the thickness of this layer were observed. The observed thickness variation is equivalent to a difference of about $0.25 \mathrm{~s}$ in two-way traveltime, which is similar to the observed variations in the traveltimes of shallow crustal reflections (Table 1). These refraction data, however, collected using on-bottom receivers and surface sources, do not have the resolution to allow the accurate determination of variations in the thickness of the Layer $2 /$ Layer 3 transition zone. High-quality refraction data, collected using both on-bottom sources and receivers, (e.g., Purdy, 1987) in an area of known upper crustal reflectivity would closely constrain the velocity structure of the reflecting horizon. Drilling such a well-surveyed reflecting horizon would set the stage for a careful investigation of the structure of the upper oceanic crust.

\section{ACKNOWLEDGMENTS}

We thank the master, crew, and science party on Cruise 2606 of the Robert D. Conrad for their help and dedication in the acquisition of the data described here. Cruise co-chief scientist John Mutter provided in- 
valuable assistance throughout the course of the experiment. Initial data reduction was carried out at Lamont-Doherty Geological Observatory, and we thank John Mutter, Peter Buhl, John Diebold, and Joyce Alsop for their help. Kristin Rohr provided advice on reprocessing the MCS data and preprints on related work. Reprocessing of the reflection data at USGS was facilitated by Jon Childs, Eric Geist, and Jill McCarthy. Steve Eittreim, Jeff Karson, Jan Morton, and Dick Von Herzen provided helpful reviews of this manuscript. The work described here was funded by National Science Foundation grants OCE-84-10658 and OCE-87-00806. Woods Hole Oceanographic Institution Contribution 7070.

\section{REFERENCES}

Anderson, R. N., Honnorez, J., Becker, K., Adamson, A. C., Alt, J. C., Emmermann, R., Kempton, P. D., Kinoshita, H., Laverne, C., Mottl, M., and Newmark, R. L., 1982. DSDP Site 504B, the first reference section over $1 \mathrm{~km}$ through Layer 2 of the oceanic crust. Nature, 300;589-594.

Anderson, R. N., O'Malley, H., and Newmark, R. L., 1985a. Use of geophysical logs for quantitative determination of fracturing, alteration, and lithostratigraphy in the upper oceanic crust, Deep Sea Drilling Project, Hole 504B and 556. In Anderson, R. N., Honnorez, J., Becker, K., et al., Init. Repts. DSDP, 83: Washington (U.S. Govt. Printing Office), 443-478.

Anderson, R. N., Zoback, M. D., Hickman, S. H., and Newmark, R. L., 1985b. Permeability versus depth in the upper oceanic crust: in situ measurements in Deep Sea Drilling Project Hole 504B, eastern equatorial Pacific. In Anderson, R. N., Honnorez, J., Becker, K., et al., Init. Repts. DSDP, 83: Washington (U.S. Govt. Printing Office), 429-442.

Archie, G. E., 1942. The electrical resistivity $\log$ as an aid in determining some reservoir characteristics. J. Petrol. Tech., 5:1-8.

Becker, K., 1985. Large-scale electrical resistivity and bulk porosity of the oceanic crust, Deep Sea Drilling Project Hole 504B, Costa Rica Rift. In Anderson, R. N., Honnorez, J., Becker, K., et al., Init. Repts. DSDP, 83: Washington (U.S. Govt. Printing Office), 419427.

Becker, K., Langseth, M. G., Von Herzen, R. P., Anderson, R. N., and Hobart, M. A., 1985. Deep crustal geothermal measurements, Hole 504B, Deep Sea Drilling Project Legs 69, 70, 83, and 92. In Anderson, R. N., Honnorez, J., Becker, K., et al., Init. Repts. DSDP, 83: Washington (U.S. Govt. Printing Office), 405-418.

Berryman, L. H., Goupillaud, P. L., and Waters, K. H., 1958. Reflections from multiple transition layers, part 1, theoretical results. Geophysics, 23:223-243.

Brandsaeter, H., Farestveit, A., and Ursin, B., 1979. A new high-resolution or deep penetration airgun array. Geophysics, 44:865-879.

Bratt, S. R., and Purdy, G. M., 1984. Structure and variability of oceanic crust on the flanks of the East Pacific Rise between $11^{\circ}$ and $13^{\circ}$ N. J. Geophys. Res., 89:6111-6125.

Casey, J. F., Dewey, J. F., Fox, P. J., Karson, J. A., and Rosencrantz, E., 1981. Heterogeneous nature of oceanic crust and upper mantle: a perspective from the Bay of Islands ophiolite complex. In Emiliani, C. (Ed.), The Sea (vol. 7): New York (Wiley), 305-338.

Christensen, N. I., and Salisbury, M. H., 1985. Seismic velocities, densities, and porosities of Layer $2 \mathrm{~B}$ and Layer $2 \mathrm{C}$ basalts from Hole 504B. In Anderson, R. N., Honnorez, J., Becker, K., et al., Init. Repts. DSDP, 83: Washington (U.S. Govt. Printing Office), 367370.

Coleman, R. G., 1977. Ophiolites, Ancient Oceanic Crust?: Berlin (Springer-Verlag).

Collins, J. A., 1989. A search for layering in the oceanic crust [Ph.D. dissert.]. Massachusetts Inst. Technol./Woods Hole Ocean. Inst. Joint Program, Woods Hole.

CRRUST, 1982. Geothermal regimes of the Costa Rica Rift, East Pacific, investigated by drilling, DSDP-IPOD Legs 68,69 , and 70 . Geol. Soc. Am. Bull., 93:862-875.

Detrick, R. S., Buhl, P., Vera, E., Mutter, J., Orcutt, J., Madsen, J., and Brocher, T., 1987. Multi-channel seismic imaging of a crustal magma chamber along the East Pacific Rise. Nature, 326:35-41.

Fuchs, K. M., and Muller, G., 1971. Computation of synthetic seismograms with the reflectivity method and comparison with observations. Geophys. J. R. Astron. Soc., 23:417-433.
Grow, J. A., and Markl, R. G., 1977. IPOD-USGS multichannel seismic reflection profile from Cape Hatteras to the Mid-Atlantic Ridge. Geology, 5:625-630.

Hale, L. D., Morton, C. J., and Sleep, N. H., 1982. Reinterpretation of seismic reflection data over the East Pacific Rise. J. Geophys. Res., 87:7707-7717.

Hamilton, E. L., 1972. Compressional-wave attenuation in marine sediments. Geophysics, 37:620-646.

1976. Sound attenuation as a function of depth in the seafloor. J. Acoust. Soc. Am., 59:528-535.

1978. Sound velocity-density relations in sea-floor sediments and rocks. J. Acoust. Soc. Am., 63:366-377.

Hashin, Z., and Shtrickman, S., 1963. A variational approach to the theory of the elastic behaviour of multiphase materials. J. Mech. Phys. Solids, 11:127-140.

Herron, T. J., Ludwig, W. J., Stoffa, P. L., Kan, T. K., and Buhl, P., 1978. Structure of the East Pacific Rise crest from multichannel seismic reflection data. J. Geophys. Res., 83:798-804.

Hill, R., 1965. A self-consistent mechanic of composite materials. $J$. Mech. Phys. Solids., 13:213-222.

Hobart, M. A., Langseth, M. G., and Anderson, R. N., 1985. A geothermal and geophysical survey on the south flank of the Costa Rica Rift: Sites 504 and 505. In Anderson, R. N., Honnorez, J., Becker, K., et al., Init. Repts. DSDP, 83: Washington (U.S. Govt. Printing Office), 517-528.

Houtz, R., and Ewing, J., 1976. Upper crustal structure as a function of plate age. J. Geophys. Res., 81:2490-2498.

Hyndman, R. D., and Drury, M., 1976. The physical properties of oceanic basement rocks from deep drilling on the Mid-Atlantic Ridge. J. Geophys. Res., 81:4042-4052.

Kennett, B.L.N., 1975. The effect of attenuation on seismograms. Bull. Seis. Soc. Am., 65:1643-1651.

Langseth, M. G., Cann, J. R., Natland, J. H., and Hobart, M., 1983. Geothermal phenomena at the Costa Rica Rift: background and objectives for drilling at Deep Sea Drilling Project Sites 501, 504 and 505. In Cann, J. R., Langseth, M. G., Honnorez, J., Von Herzen, R. P., White, S. M., et al., Init. Repts. DSDP, 69: Washington (U.S. Govt. Printing Office), 5-29.

Langseth, M. G., Mottl, M. J., Hobart, M. A., and Fischer, A., 1988. The distribution of geothermal and geochemical gradients near Site 501/504: implications for hydrothermal circulation in the oceanic crust. In Becker, K., Sakai, H., et al., Proc. ODP, Init. Repts., 111: College Station, TX (Ocean Drilling Program), 23-32.

Larner, K., Chambers, R., Yang, M., Lynn, W., and Wai, W., 1983. Coherent noise in marine seismic data, Geophysics, 48:854-886.

Lewis, B.T.R., 1983. The processes of formation of ocean crust. Science, 220:151-157.

Little, S. A., and Stephen, R. A., 1985. Costa Rica Rift borehole seismic experiment, Deep Sea Drilling Project Hole 504B, Leg 92. In Anderson, R. N., Honnorez, J., Becker, K., et al., Init. Repts. $D S D P, 83$ : Washington (U.S. Govt. Printing Office), 517-528.

Mallick, S., and Frazer, L. N., 1987. Practical aspects of reflectivity modeling. Geophysics, 52:1355-1364.

McCarthy, J., Mutter, J. C., Morton, J. L., Sleep, N. H., and Thompson, G. T., 1988. Relic magma chamber structures preserved within the Mesozoic North Atlantic crust? Geol. Soc. Am. Bull., 100:14231436.

Moos, D., Goldberg, D., Hobart, M. A., and Anderson, R. N., 1986. Elastic wave velocities in Layer $2 \mathrm{~A}$ from full waveform sonic logs at Hole 504B. In Leinen, M., Rea, D. K., et al., Init. Repts. DSDP, 92: Washington (U.S. Govt. Printing Office), 563-570.

Morton, J. L., and Sleep, N. H., 1985. Seismic reflections from a Lau Basin magma chamber. In Scholl, D. W., and Vallier, T. L. (Eds.), Geology and Offshore Resources of Pacific Island Arcs-Tonga Region, 3: Houston, TX (Circum-Pacific Council for Energy and Mineral Resources), 441-453.

Musgrove, L. A., and Austin, J. A., 1983. Intrabasement structure in the southern Angola Basin. Geology, 11:169-173.

Mutter, J. C., and North Atlantic Transect (NAT) Study Group, 1985. Multichannel seismic images of the oceanic crust's internal structure: evidence for a magma chamber beneath the Mesozoic Mid-Atlantic Ridge. Geology, 13:629-632.

Newmark, R. L., Anderson, R. N., Moos, D., and Zoback, M. D., 1985. Sonic and ultrasonic logging of Hole 504B and its implications 
for the structure, porosity and stress regime of the upper $1 \mathrm{~km}$ of the oceanic crust. In Anderson, R. N., Honnorez, J., Becker, K., et al. Init. Repts. DSDP, 83: Washington (U.S. Govt. Printing Office), 479-510.

Purdy, G. M., 1987. New observations of the shallow seismic structure of young oceanic crust. J. Geophys. Res., 92:9351-9362.

Purdy, G. M., and Ewing, J. I., 1986. Seismic structure of oceanic crust. In Tulcholke, B. E., and Vogt, P. R. (Eds.), The Geology of North America: The Western Atlantic Region: Geol. Soc. Am. DNAG Ser., 1:313-331.

Rohr, K.M.M., Milkereit, B., and Yorath, C. J., 1988. Asymmetric structure across the Juan de Fuca Ridge. Geology, 16:533-537.

Salisbury, M. H., Christensen, N. I., Becker, K., and Moos, D., 1985. The velocity structure of Layer 2 at Deep Sea Drilling Project Site 504 from logging and laboratory experiments. In Anderson, R. N., Honnorez, J., Becker, K., et al., Init. Repts. DSDP, 83: Washington (U.S. Govt. Printing Office), 529-539.

Searle, R. C., 1983. Gloria survey over Costa Rica Rift: Sites 501, 504 and 505. In Cann, J. R., Langseth, M. G., Honnorez, J., Von Herzen, R. P., White, S. M., et al., Init. Repts. DSDP, 69: Washington (U.S. Govt. Printing Office), 217-222.

Shipboard Scientific Party, 1988. Site 504, Costa Rica Rift. In Becker, K., Sakai, H., et al., Proc. ODP, Init. Repts., 111: College Station, TX (Ocean Drilling Program), 35-251.
Stephen, R. A., 1977. Synthetic seismograms for the case of the receiver within the reflectivity zone. Geophys. J. R. Astron. Soc., 51:169181 .

1983. A comparison of finite difference and reflectivity seismograms for marine models. Geophys. J. R. Astron. Soc., 72:3958 .

1985. Seismic anisotropy in the upper oceanic crust. J. Geophys. Res., 90:11,383-11,396.

Stoffa, P. L., Buhl, P., Herron, T. J., Kan, T. K., and Ludwig, W. J., 1980. Mantle reflections beneath the crestal zones of the East Pacific Rise from multichannel reflection data. Mar. Geol., 35:83-97.

Watt, J. P., Davies, G. F., and O'Connell, R. J., 1976. The elastic properties of composite materials. Rev. Geophys., 14:541-563.

Wilkens, R. H., and Langseth, M. G., 1983. Physical properties of sediments of the Costa Rica Rift, Deep Sea Drilling Project Sites 504 and 505. In Cann, J. R., Langseth, M. G., Honnorez, J., Von Herzen, R. P., White, S. M., et al., Init. Repts. DSDP, 69: Washington (U.S. Govt. Printing Office), 659-674.

Date of initial receipt: 14 November 1988

Date of acceptance: 6 February 1989

Ms 111B-154 